\title{
Effect of Saline Irrigation Water, Gibberellic Acid(GA3) and Biofertilizers on Growth, Flowers Yield and Oil Production of Matricaria Chamomilla, L.plants
}

\author{
A. H. El-Naggar, * , M. R. Hassan* A.A.Abd El-Salam**M.A.Abdelgawad* \\ * Floriculture, Ornamental Horticulture and landscape Gardening Dept., \\ Faculty of Agric., (EL-Shatby), Alexandria Univ. Egypt. \\ **Soil and Water Sciences Dept., Faculty of Agric.(EL-Shatby), Alexandria Univ., Egypt.
}

\begin{abstract}
The present study was conducted to investigate the effects of salinity, gibberellic acid (GA3) and biofertilizers on growth, flowering and oil yield of Matricaria chamomilla, L. var. " German chamomile " plants. The experiment was designed as a split-split plot design in three replicates. The main plot represented different concentrations of saline irrigation water ( tap water , 3 and $6 \mathrm{dSm}-1$ ) . The sub-plot was gibberellic acid (GA3) as foliar application at four levels $0.0,100$ and $200 \mathrm{mg} \mathrm{L}-1$. The sub sub-plot represented bio-fertilizers [nitrobine + phosphorein $1: 1 \mathrm{w} / \mathrm{w}$ ] at rates of $0.0,5.0$ and $10.0 \mathrm{~g} /$ plant . The best treatment due to these combination was resulted from irrigation plants with fresh or moderate saline water at EC $3 \mathrm{dSm}-1$ combined with spraying with all levels of GA3 combined with biofertilizer application at 5.0 and $10.0 \mathrm{~g} /$ plant on growth and flowering characteristics. Maximum oil percentage resulted from irrigation with saline water and application the highest levels of GA3 and biofertilizer. Combination of fresh water, $200 \mathrm{mg} \mathrm{L}-1 \mathrm{GA} 3$ and $10 \mathrm{~g}$ nitrobein $+10 \mathrm{~g}$ phosporein per pot produced the maximum essential oil yield /plant .

Key words: Medicinal and Aromatic Plants, Chamomile, Matricaria chamomilla, L., salinity, gibberellic acid, biofertilizers and, Essential oil.
\end{abstract}

\section{INTRODUCTION}

Chamomile (Asteraceae; Matricaria Chamomilla, L.) is considered one of the oldest, most widely used and well documented medicinal plants in the world The original habitat of chamomile species are Northern Africa, Asia, Southern and Eastern Europe. Chamomile is an annual plant. It has a thin spindle shaped roots only penetrating flatly into the soil. The branched stem is upright, heavily ramified, and grows to a height of $10-80 \mathrm{~cm}$. The long and narrow leaves are bi- to tripinnate. The flower heads are placed separately, they have a diameter of $10-30 \mathrm{~mm}$, and they are pedunculate and heterogamous. The golden yellow tubular florets with 5 teeth are $1.5-2.5 \mathrm{~mm}$ long, It always ends in a glandulous tube. The 11-27 white plant florets are wide (3.5) $\mathrm{mm}$, long 6-11 $\mathrm{mm}$, and arranged concentrically. The receptacle is $6-8 \mathrm{~mm}$ wide, flat in the beginning and conical, cone-shaped later, hollow-the latter being a very important distinctive feature of Matricaria chamomilla - and without paleae. The fruit is a yellowish brown achene (Franz et al., 2005).

Chamomile is a well-known medicinal plant in folk medicine cultivated all over the world. Chamomile essential oil is widely used in pharmaceutics, cosmetic, and food industries. The biologically active substances in Chamomile essential oil are trans - $\beta$-farnesene, $\alpha$-bisabolol, bisabolol oxides, chamazulene, 
and enyn-diccycloethers ( Brunke et al., 1992 and Grgesina et al.,1995). The flowers heads are the main organs of the production of essential oil, It may exceed 120 chemical constituents in chamomile flower as secondary metabolites, including 28 terpenoids, 36 flavonoids, and 52 additional compounds (Mann and Staba, 2002).

Saline irrigation water is considered detrimental to most crop plants. Even salt-resistant plants show decrease in yield when grown under saline irrigation. However, saline water is available in abundance in many countries of the world, thus, the importance of establishing agro-management regimes that include saline water is self-evident . In arid and semi arid regions, salinity has been recognized as an important factor influencing crop production and agricultural sustainability. On the other hand, irrigation with saline water without proper management, such as mixing with fresh water, would produce adverse effects on crop yield and soil productivity due to deterioration of soil quality.(Afifi et al., 1998), Morsy (2003).

Gibberellic acid is among the many plant hormones, It had an axis the main focus of some plant scientists to relieve the negative effects of salinity (Basalah and Mohammad, 1999). Available information about the effect of GA3 on the growth of plants under salinity it may be limited and few reports have stated the ability of GA3 to reduce the negative effects of salinity (Misratia et al., 2013).Use of The exogenous applications of gibberellic acid leads to some benefit in relieve the adverse effects of salt stress and also improves growth, development and yield quality and seed yields (Javid et al., 2011). It was reported that foliar application of GA3 improved chlorophyll content and water use efficiency (Misratia et al., 2013).

Bio-fertilizers are reasonably safer to the environment and play an important role in decreasing the use of chemical fertilizers. Consequently, it cause a reduction in environmental pollution. Bio fertilizers are microbial inoculants consisting of living cells of micro-organism like bacteria, algae and fungi alone or combination which may help in increasing crop productivity. Bio fertilizers can influence plant growth directly through the production of phytohormones such as gibberellins, cytokinins and IAA that act as growth regulators and indirectly through nitrogen fixation and production of bio-control agents against soil-borne phytopathogens and consequently increase formation of metabolites which encourage the plant vegetative growth and enhance the meristematic activity of tissues to produce more growth (Ahmed and Kibret, 2014).

The objectives of the present study were to investigate the effect of the salinity with different gibberellic acid concentrations, biofertilizers applications 
and their interactions on the growth, flowering parameters and quantity of the essential oil of Matricaria Chamomilla, L. plants.

\section{MATERIALS AND METHODS}

The pot experimental study was carried out during two successive seasons of 2015 /2016 and 2016/2017 at the Nursery, Department of Floriculture, Ornamental Horticulture and Landscape Gardening, Faculty of Agriculture, Alexandria University, Egypt.

The plant used in this experiment was chamomile (Matricaria Chamomilla L. var." German chamomile ").

In the first season 2015/2016, Seedlings were obtained used in the experiment, uniformly shaped seedlings from a commercial nursery in (Kerdasa) in Cairo (planted its seeds on 2nd October 2015)Which reached, the average seedling length is $15 \mathrm{~cm}$ (one seedling per pot and an average of 15-20 leaves per seedling ) were transplanted to the final pot, $30 \mathrm{~cm}$ diameter filled with clay, sand and cattle manure $(2: 1: 1)$ on 3rd December 2015 in full sunny place. In the second season 2016/2017, The seeds resulting from the first season were planted on 4th October 2016, and seedlings were selected from them with the same specifications as the seedlings of the first season. They were planted according to the standards of the first season in the final pot on December 6th, 2016 respectively. Chemical properties of the growing media used in the study are presented in Table 1 .

Table(1)Some Physical and chemical analysis of the chosen growing media according to Jackson ( 1973 )

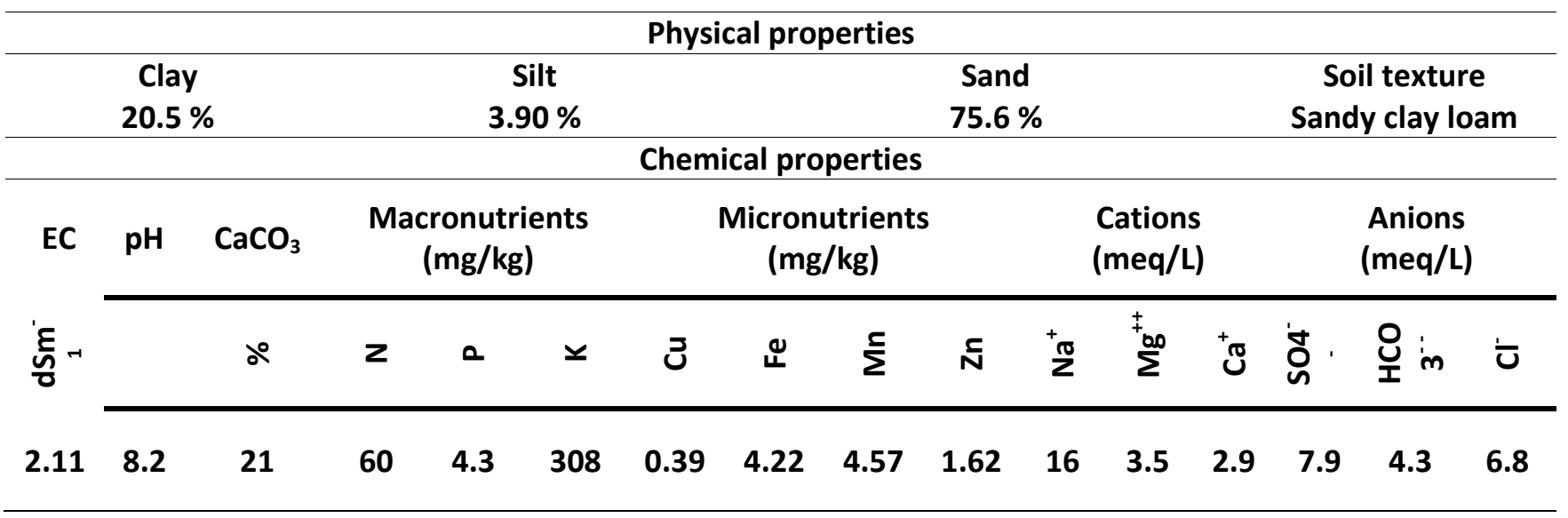

\section{Experimental treatments and layout:}

The experimental treatments were consisted of three concentrations of saline water Sodium chloride i.e. (tap water as control) $0.56 \mathrm{dSm}-1,3 \mathrm{dSm}-1$ and $6 \mathrm{dSm}-1$ used. Salinity levels were obtained by addition of appropriate amount of dry $\mathrm{NaCl}$ to water. (Saline irrigation water started after 14 days from planting of the seedlings, alternatively irrigation every 3 days with saline and tap 
water for two months and three levels of gibberillic acid (GA3) at 0,100 and $200 \mathrm{mg} \mathrm{L}-1$ were sprayed three times after 30, 45, 60 days from the transplanting. The biofertilizer was used either nitrobein contained nitrogen fixing-bacteria (Azotobacter and Azospirillum) and phosphorein (a biofertilizer contains a specific clone of bacteria which changes the unavailable triphosphate to available monophosphate ) were mixed with the surface layer of the soil It was added two times, the first was immediately added at direct transplanting and the second was added after one month later B0 (without biofertilizer), B1 (5 g nitrobein $+5 \mathrm{~g}$ phosphorein) and B2 (10 g nitrobein $+10 \mathrm{~g}$ phosphorein) per plant.

\section{Experimental layout and statistcal analysis}

The experiment layout was designed to provide a split-split plot experimental design which containing three replicates, each replicate contained (27 treatments). Three (3) pots were used as a plot for each treatment (Snedecor and Cochran, 1981).

The whole plots were represented by three Salinity treatments. The sub plots were randomly assigned the three gibberillic acid treatment (GA3) levels and the sub-sub plots were described the three treatments of biofertilizers.

\section{Morphological Measurements:}

1- Vegetative growth characteristics: Plant height $(\mathrm{cm})$, plant total fresh weight (g), total dry weight (g) Conducted 70 days after transplanting .

2- Yield parameters : Number of flower heads per plant, fresh weight of flowers yield $(\mathrm{g})$, dry weight of flowers yield $(\mathrm{g})$ (The beginning of collecting inflorescences with the end of December and the beginning of January).

\section{Essential Oil}

The oil percentage was determined by water distillation method according to the (British Pharmacopoeia, 1963), where the flower from each sample $(50 \mathrm{~g}$ fresh flower) were placed in the flask of two liters capacity (the amount of water and sample was $2 / 3$ from flask ). A proper essential oil trap and condenser were attached to the flask. The distillation was continued for $5-7$ hours until no further increase in the oil was observed.

1 -Essential oil percentage (\%)

Essential oil \% = Oil volume (reading measured pipette) / weight of sample (g) $\times 100$.

2-Essential oil yield

Oil yield/plant= Oil percentage $\times$ fresh weight of flower heads per plant.

The same steps and techniques of the first experimental year 2015/2016 were followed in the second one 2016/2017.

The GC analysis of the volatile oil samples was carried out using gas chromatograph instrument stands at the Medicinal and Aromatic Plants Dept. Laboratory, Horticulture Research Institute (Agricultural Research Center,Cairo, Egypt, Ministry of Agriculture and land Reclamation) 
The data were statistically analyzed according to the methods described by Snedecor and Cochran, (1981) using L.S.D. to compare between means of the treatments.

\section{RESULTS AND DISCUSSION}

Results presented in Table (2) showed that height of chamomile plants was significantly affected by irrigation water salinity, gibberillic acid concentrations, biofertilizer applications and their interactions in seasons 2016 and 2017, except the interaction between the salinity levels and $\mathrm{GA}_{3}$ concentration in the second seasons.

Plant height of chamomile gradually decreased with increasing salinity level, where the tallest plants of 41.45 and $54.55 \mathrm{~cm}$ in the first and second seasons, respectively, resulted by using tap water, however the shortest plants of 39.24 and $50.76 \mathrm{~cm}$ in the two successive seasons resulted by using saline irrigation water ( $\mathrm{EC}, 6 \mathrm{dSm}^{-1}$ ). The decrease in plant height resulted from soil salinity might be attributed to the inhibition of both meristematic activity and elongation of cells (Neiman,1965). Tuna et al.(2008) also reported that decreasing plant height with increasing salinity levels resulting to inadequate water uptake and hence, relative water content (RWC) was significantly decreased and resulted in limited water availability for the cell extension process. Similar results were obtained by many researches as Ali and Hassan (2012) on Matricaria chamomilla, . GA 3 application at 100 or 200 $\mathrm{mg} \mathrm{L}^{-1}$ significantly increased plant height by 15.79 and $13.38 \%$ respectively, in the first season and 8.29 and $8.69 \%$ in the second season compared with control, however the difference between 100 and $200 \mathrm{mg} \mathrm{L}^{-1}$ did not reach significantly level. These results might be due to the promotive effect of gibberillins on increasing the auxin level of tissue or cause cell division and cell elongation (Kuraishi and Muri,1964). Similar results were reported by Saedi and Al-Rubaiee(2012) on Matricaria chamomilla, and Atteya and ElGendy(2018) on Tagetes patula.

Data in the previous Table, also showed that increasing biofertilizers gradually increased chamomile plant height and the maximum heights were 40.90 and $53.33 \mathrm{~cm}$ in the two successive seasons resulted from $10 \mathrm{~g}$ nitrobein $+10 \mathrm{~g}$ phosphorein application. The positive effect of biofertilizers are in line with those obtained by Gewaily et al.(2006) who reported that biofertilizer

application enhanced the vegetative growth and plant height of Majorana hortensis L. Similar results were reported by El-Naggar et al. (2015) on Ocimum basilicum .

Concerning the three factors interaction effect on chamomile plant height, data in Table (2) demonstrated that the tallest plants in the two seasons, generally resulted from irrigation with unsaline water combined with 100 or $200 \mathrm{mg} \mathrm{L}^{-1}$ of gibberillic acid and biofertilizers $(5 \mathrm{~g}$ or $10 \mathrm{~g}$ nitrobein $+5 \mathrm{~g}$ or $10 \mathrm{~g}$ phosphorein) per pot. These results could be due to the positive integrated effect of gibberillic acid and biofertilizer to alleviate the stress of salinity on plant growth, where Azospirillum brasilense produced plant 
hormones, especially growth promoters and supply plants with combined nitrogen. These results agreed with those reported by Ali and Hassan (2012) on Matricaria chamomilla.

Table (2):Effect of water salinity, GA3, biofertilizer and their interactions on plant height $(\mathrm{cm})$ of Matricaria chamomilla L. plants in the seasons of 2016 and 2017.

\begin{tabular}{|c|c|c|c|c|c|c|c|}
\hline \multirow{3}{*}{$\begin{array}{c}\text { Water } \\
\text { Salinity } \\
\text { (A) } \\
\mathrm{dSm}^{-1}\end{array}$} & \multirow{3}{*}{$\begin{array}{c}\mathrm{GA}_{3} \\
(\mathrm{~B}) \\
\mathrm{mg} \mathrm{L}^{1}\end{array}$} & \multicolumn{3}{|c|}{$\begin{array}{l}\text { First season } \\
(2015 \text { / 2016) }\end{array}$} & \multicolumn{3}{|c|}{$\begin{array}{c}\text { Second season } \\
(2016 / 2017)\end{array}$} \\
\hline & & \multicolumn{3}{|c|}{ Biofertilizer(C) } & \multicolumn{3}{|c|}{ Biofertilizer(C) } \\
\hline & & $\mathrm{B}_{0}$ & $\mathrm{~B}_{1}$ & $\mathrm{~B}_{2}$ & $\mathrm{~B}_{0}$ & $B_{1}$ & $B_{2}$ \\
\hline \multirow{3}{*}{ TW } & 0 & 37.72 & 38.44 & 36.89 & \multirow{3}{*}{$\begin{array}{c}49.78 \\
53.5654 .44\end{array}$} & 48.11 & 55.33 \\
\hline & 100 & 41.06 & 45.89 & 46.17 & & 57.33 & 59.00 \\
\hline & 200 & 41.89 & 41.89 & 43.17 & & 57.78 & 55.78 \\
\hline \multirow{4}{*}{3} & 0 & 37.33 & 35.39 & 35.94 & 50.33 & 46.89 & 51.56 \\
\hline & 100 & 43.39 & 42.23 & 41.56 & 54.00 & 51.11 & 53.22 \\
\hline & 200 & 39.78 & 39.44 & 41.17 & 54.67 & 54.33 & 53.67 \\
\hline & 0 & 34.89 & 36.11 & 36.17 & 46.78 & 48.11 & 50.44 \\
\hline \multirow[t]{2}{*}{6} & 100 & 36.83 & 38.61 & 45.0 & 53.67 & 55.22 & 47.22 \\
\hline & 200 & 41.28 & 42.17 & 42.11 & 49.22 & 52.44 & 53.78 \\
\hline \multicolumn{2}{|c|}{ TW } & 40.22 & 42.07 & 42.07 & 52.59 & 54.37 & 56.70 \\
\hline \multicolumn{2}{|c|}{3} & 40.16 & 39.05 & 39.54 & 52.99 & 50.77 & 52.81 \\
\hline \multicolumn{2}{|c|}{6} & 37.66 & 38.96 & 41.09 & 49.88 & 51.92 & 50.48 \\
\hline $\mathrm{GA}_{3}$ & 0 & 36.64 & 36.64 & 36.33 & 48.96 & 47.66 & 52.44 \\
\hline \multicolumn{2}{|c|}{100} & 40.42 & 42.27 & 44.23 & 53.74 & 54.55 & 53.14 \\
\hline \multicolumn{2}{|c|}{200} & 40.98 & 41.16 & 42.14 & 52.77 & 54.85 & 54.40 \\
\hline \multicolumn{2}{|c|}{ W.S. $\times \mathrm{GA}_{3}$} & Omg L- & $100 \mathrm{mg} \mathrm{L}^{1}$ & $200 \mathrm{mg} \mathrm{L}^{-1}$ & $0 \mathrm{mg} \mathrm{L}-{ }^{1}$ & $100 \mathrm{mg} \mathrm{L}^{-1}$ & $\begin{array}{c}200 \mathrm{mg} \\
\mathrm{L}-{ }^{1}\end{array}$ \\
\hline \multicolumn{2}{|c|}{ TW } & 37.68 & 44.37 & 42.31 & 51.03 & 56.62 & 56.00 \\
\hline \multicolumn{2}{|c|}{3} & 36.22 & 42.41 & 40.12 & 49.59 & 52.77 & 52.03 \\
\hline \multicolumn{2}{|c|}{6} & 35.72 & 40.14 & 41.85 & 48.44 & 52.03 & 51.81 \\
\hline \multicolumn{2}{|c|}{ W.S } & $\begin{array}{l}\text { T.W. } \\
41.45\end{array}$ & $\begin{array}{c}3 \mathrm{dsm} \mathrm{m}^{-1} \\
39.59\end{array}$ & $\begin{array}{c}6 \mathrm{dsm}^{-1} \\
39.24\end{array}$ & $\begin{array}{c}\text { T.W. } \\
54.55\end{array}$ & $\begin{array}{c}3 \mathrm{dsm}^{-1} \\
52.19\end{array}$ & $\begin{array}{c}6 \mathrm{dsm}^{-1} \\
50.76\end{array}$ \\
\hline \multirow{2}{*}{\multicolumn{2}{|c|}{$\mathrm{GA}_{3}$}} & $\underset{1}{0 \mathrm{mg}} \mathrm{L}-$ & $100 \mathrm{mg} \mathrm{L}^{-1}$ & $200 \mathrm{mg} \mathrm{L}^{1}$ & Omg L-1 & $100 \mathrm{mg} \mathrm{L}^{-1}$ & $200 \mathrm{mg}_{1} \mathrm{~L}-$ \\
\hline & & 36.54 & 42.31 & 41.43 & 49.69 & 53.81 & 54.01 \\
\hline \multicolumn{2}{|c|}{ Bio } & $\begin{array}{c}\mathrm{B}_{0} \\
39.35\end{array}$ & $\begin{array}{c}B_{1} \\
40.03\end{array}$ & $\begin{array}{c}B_{2} \\
40.90\end{array}$ & $\begin{array}{c}\mathrm{B}_{0} \\
51.82\end{array}$ & $\begin{array}{c}\mathrm{B}_{1} \\
52.35\end{array}$ & $\begin{array}{c}B_{2} \\
53.33\end{array}$ \\
\hline \multicolumn{5}{|c|}{$\begin{array}{ll}\text { L.S.D } & \\
A=05 & \\
A=2.11 & B=1.96 \\
C=1.34 & A \times B=3.40 \\
A \times C=2.32 & B \times C=2.32 \\
A \times B \times C=4.03 & \end{array}$} & $\begin{array}{l}A=3.40 \\
C=1.34 \\
A \times C=2.69 \\
A \times B \times C=\end{array}$ & $\begin{array}{c}B=2.20 \\
A \times B=N . S \\
B \times C=2.69 \\
.67\end{array}$ & \\
\hline
\end{tabular}




\subsection{Total fresh weight $(\mathrm{g})$ per plant.}

Total fresh weight of chamomile plant significantly affected by salinity levels, gibberillic acid concentrations, biofertilization application rates and their interactions in seasons of 2016 and 2017, except GA3 combined with biofertilizer levels and GA3 x salinity levels in the first and second seasons, respectively (Table 3 ).

Increasing salinity levels to $6 \mathrm{dSm}-1$ significantly decreased chamomile plant fresh weight by 2.24 and 5.34 (g) in 2016 and 2017 seasons, respectively. In this respect, The decrease in fresh weight might be due to the high level of salinity which increased osmotic pressure and caused a drop in plant water content and inhibition of both meristamatic activity and elongation of cells, or at might return the reduction in weight to inhibition of the biosynthesis foods and their translocation to the growing shoots. These results are in general agreement with those reported by Heidari and Sarani(2012) on Matricaria chamomilla and Estaji et al.(2018) on Satureja hortensis.

Spraying chamomile plants with gibberillic acid up to $200 \mathrm{mg} \mathrm{L}$ 1significantly increased plant fresh weight, however the difference between 100 and $200 \mathrm{mg} \mathrm{L}-1$ was insignificant in the two seasons of study. the increases were 4.57 and $8.33 \%$ and 9.31 and $14.51 \%$ as increasing GA3 concentrations up to $200 \mathrm{mg} \mathrm{L}-1$ in the first and second seasons, respectively. The promotive effect of gibberillins on growth may be increasing the auxin level of tissue or enhance the conversion of tryptophan to IAA, which cause cell division and cell elongation .Similar results were obtained by Reda et al.(2010) on Chamomile recutita.

Concerning biofertilizer application effect on that trait, presented results in Table (3) revealed that $10 \mathrm{~g}$ nitrobein $+10 \mathrm{~g}$ phosphorein per plant produced the highest plant fresh weight 35.54 and $45.82 \mathrm{~g}$ in the two successive seasons, however the difference between $(5 \mathrm{~g}$ nitrobien $+5 \mathrm{~g}$ phoshorein) and control did not reach the significance level. The positive effect of biofertilizer might be due to promote plant growth and phytohormones and bio-control agents production against soil- borne phytopathogens (Cohen et al.,2007). The present results are in general agreement with those obtained by Shalan et al.(2001) on chamomile, and Mahfouz et al. (2003) on Majorana hortensis moench.

With respect to salinity levels with gibberillic acid concentrations combined with biofertilizer levels interaction effect on chamomile plant fresh weigh, results presented in Table (3) showed that the highest plant fresh weights 44.0 and $37.79 \mathrm{~g}$ resulted from irrigation with saline water( EC, 3 $\mathrm{dSm}-1$ ), fertilized with $10 \mathrm{~g}$ nitrobein $+10 \mathrm{~g}$ phosporein and spraying with 100 and $200 \mathrm{mg} \mathrm{L}-1 \mathrm{GA} 3$ concentrations. Also, using saline water ( EC, $6 \mathrm{dSm}-1$ ) and $10 \mathrm{~g}$ nitrobein $+10 \mathrm{~g}$ phosphorein per plant without gibberillic acid application, however, using tap water, generally produced the highest plant fresh weight and GA3 and biofertilizer application in the first season. 
Fertilized chamomile plants with $5 \mathrm{~g}$ nitrobein $+5 \mathrm{~g}$ phosphorein combined with $200 \mathrm{mg} \mathrm{L}$-1giberrillic produced the highest plant fresh weight 49.95 and $50.30 \mathrm{~g}$ using tap water and saline water $(6 \mathrm{dsm}-1)$, respectively, in the second season. Under ( EC, $3 \mathrm{dSm}-1$ ) salinity level, $10 \mathrm{~g}$ nitrobein $+10 \mathrm{~g}$ phosphorein without GA3 application or $200 \mathrm{mg} \mathrm{L}-1$, also produced the highest plant fresh weight 50.21 and $52.33 \mathrm{~g}$, while using $5 \mathrm{~g}$ nitrobein $+5 \mathrm{~g}$ phosphorein and spraying 100 and $200 \mathrm{mg} \mathrm{L}-1 \mathrm{GA} 3$ under the same salinity level, also produced the highest fresh weight per chamomile plant 53.45 and $56.05 \mathrm{~g}$, respectively, as shown in Table (3). Improvement of chamomile plants growth by gibberillic acid application could result in an enlargement of leaf area, the motivation of cell division and / or cell elongation, simulation of photosynthetic rate, modified partitioning of photosynthates, or in their combinations. Also GA3 accumulates of hexoses which considered important for the primary cell wall biosynthesis, accordingly enhancing plant growth under saline stress conditions (Khan et al., 2015). On the other hand, Morteza et al. (2013) on Lippia citriodors, recorded positive effects of biofertilizers on plant growth as a result of increasing photosynthesis tissuse by promoting the absorption of nitrogen and phosphorus that have effects chlorophyll production and plant essential enzymes preparing. 
Table (3): Effect of water salinity, GA3, biofertilizer and their interactions on total fresh weight / plant(g) of Matricaria chamomilla L. plants in the seasons of 2016 and 2017.

\begin{tabular}{|c|c|c|c|c|c|c|c|}
\hline \multirow{2}{*}{$\begin{array}{c}\text { Water } \\
\text { Salinity } \\
\text { (A) }\end{array}$} & \multirow{3}{*}{$\begin{array}{c}\text { GA3 } \\
\text { (B) } \\
\text { mg L-1 }\end{array}$} & \multicolumn{3}{|c|}{$\begin{array}{l}\text { First season } \\
(2015 \text { / 2016) }\end{array}$} & \multicolumn{3}{|c|}{$\begin{array}{c}\text { Second season } \\
(2016 / 2017)\end{array}$} \\
\hline & & \multicolumn{3}{|c|}{ Biofertilizer(C) } & \multicolumn{3}{|c|}{ Biofertilizer(C) } \\
\hline & & BO & B1 & B2 & BO & B1 & B2 \\
\hline \multirow{3}{*}{ TW } & 0 & 31.01 & 30.80 & 35.22 & 43.07 & 38.24 & 48.33 \\
\hline & 100 & 35.52 & 35.76 & 32.99 & 49.07 & 47.71 & 45.80 \\
\hline & 200 & 39.16 & 36.40 & 36.87 & 42.10 & 49.95 & 47.89 \\
\hline \multirow{3}{*}{3} & 0 & 32.28 & 29.79 & 31.46 & 45.08 & 46.76 & 50.21 \\
\hline & 100 & 32.92 & 33.19 & 44.00 & 49.33 & 53.45 & 44.46 \\
\hline & 200 & 32.21 & 32.19 & 37.79 & 45.53 & 56.05 & 52.33 \\
\hline \multirow{3}{*}{6} & 0 & 31.80 & 32.72 & 36.67 & 36.24 & 33.66 & 34.36 \\
\hline & 100 & 29.94 & 31.52 & 29.32 & 32.71 & 41.34 & 48.10 \\
\hline & 200 & 31.91 & 34.02 & 35.54 & 45.41 & 50.30 & 40.93 \\
\hline \multicolumn{2}{|c|}{ TW } & 35.22 & 34.32 & 35.02 & 44.41 & 45.30 & 47.33 \\
\hline \multicolumn{2}{|c|}{3} & 32.47 & 31.72 & 37.74 & 46.64 & 52.08 & 48.99 \\
\hline \multicolumn{2}{|c|}{6} & 31.21 & 32.75 & 33.86 & 38.13 & 41.76 & 41.13 \\
\hline \multicolumn{2}{|c|}{ GA3 0} & 31.69 & 31.10 & 34.47 & 41.48 & 39.55 & 44.29 \\
\hline \multicolumn{2}{|c|}{100} & 32.79 & 33.49 & 35.43 & 43.36 & 47.50 & 46.12 \\
\hline \multicolumn{2}{|c|}{200} & 34.42 & 34.20 & 36.73 & 44.34 & 52.10 & 47.04 \\
\hline \multicolumn{2}{|c|}{ W.S. $\times$ GA3 } & $\begin{array}{c}0 \\
m g ~ L-1\end{array}$ & $\begin{array}{c}100 \\
\mathrm{mg} \mathrm{L}-1\end{array}$ & $\begin{array}{c}200 \\
\mathrm{mg} \mathrm{L}-1\end{array}$ & $\begin{array}{c}0 \\
m g ~ L-1\end{array}$ & $\begin{array}{c}100 \\
\mathrm{mg} \mathrm{L}-1\end{array}$ & $\begin{array}{c}200 \\
\mathrm{mg} \mathrm{L}-1\end{array}$ \\
\hline \multicolumn{2}{|c|}{ TW } & 32.34 & 34.75 & 37.47 & 43.21 & 47.19 & 46.64 \\
\hline \multicolumn{2}{|c|}{3} & 31.17 & 36.70 & 34.06 & 47.34 & 49.08 & 51.30 \\
\hline \multicolumn{2}{|c|}{6} & 33.75 & 30.26 & 33.82 & 34.77 & 40.71 & 45.54 \\
\hline \multirow{2}{*}{\multicolumn{2}{|c|}{ W.S }} & T.W. & $3 \mathrm{dsm}-1$ & $6 \mathrm{dsm}-1$ & T.W. & $3 \mathrm{dsm}-1$ & $6 \mathrm{dsm}-1$ \\
\hline & & 34.85 & 33.98 & 32.61 & 45.68 & 49.24 & 40.34 \\
\hline \multirow{3}{*}{\multicolumn{2}{|c|}{ GA3 }} & 0 & 100 & 200 & 0 & 100 & 200 \\
\hline & & $\mathrm{mg} \mathrm{L}-1$ & $\mathrm{mg} \mathrm{L}-1$ & $\mathrm{mg} \mathrm{L}-1$ & $\mathrm{mg} \mathrm{L}-1$ & $\mathrm{mg} \mathrm{L}-1$ & $\mathrm{mg} \mathrm{L}-1$ \\
\hline & & 32.42 & 33.90 & 35.12 & 41.77 & 45.66 & 47.83 \\
\hline \multirow{2}{*}{\multicolumn{2}{|c|}{ Bio }} & B0 & B1 & B2 & B0 & B1 & B2 \\
\hline & & 32.97 & 32.93 & 35.54 & 43.06 & 46.38 & 45.82 \\
\hline \multicolumn{5}{|c|}{$\begin{array}{l}\text { L.S.D } 0.05 \\
A=2.44 \quad B=2.11 \\
C=2.44 \quad A \times B=3.66 \\
A \times C=2.75 \quad B \times C=N . S \\
A \times B \times C=4.76\end{array}$} & $\begin{array}{l}A=5.28 \\
C=2.22 \\
A \times C=3.85 \\
A \times B \times C=\end{array}$ & \multicolumn{2}{|c|}{$\begin{array}{l}B=2.67 \\
A \times B=N . S \\
B \times C=3.85 \\
6.67\end{array}$} \\
\hline
\end{tabular}




\subsection{Total dry weight /plant (g).}

Total dry weight of chamomile plant as presented in Table (4) was significantly affected by salinity levels, gibberillic acid concentrations andbiofertilizer rates besides their interactions in the two studied seasons.

Irrigated chamomile plants with tap water (unsaline water) produced the highest plant dry weights of 11.72 and $15.28 \mathrm{~g}$, in 2016 and 2017 growing seasons, respectively. Conversely, saline water ( EC, 3 and $6 \mathrm{dSm}-1$ ) in the first season and (EC, 3dSm-1) in the second season produced the lowest plant dry weights $(10.51,10.50$ and $13.68 \mathrm{~g})$, respectively. In this respect, decreasing fresh and dry weight of herb with increasing salinity levels may be due to the decrease in the growth resulting from the inhibition of photosynthesis that reduced carbohydrates storage(Ahmed et al.,2011). These results agree with those obtained by Deepika et al.(2015)onMatricaria chamomilla, and Estaji et al.(2018) on Satureja hortensis.

Results presented in that Table, also, indicated that the highest total dry weights of chamomile plants $11.90,15.02$ and $16.14 \mathrm{~g}$ resulted from spraying gibberillic acid by $200 \mathrm{mg} \mathrm{L}-1$ in 2016 and 100 and $200 \mathrm{mg} \mathrm{L-1in}$ season 2017, respectively. This increase might be due to the promotive effect of gibberillins on plant growth on increasing the level of auxin of tissues or enhance the conversion of tryptophan to IAA, which cause cell division and cell elongation (Kurashi and Muir, 1964). Increasing biofertilizer levels gradually increased plant total dry weight and $10 \mathrm{~g}$ nitrobein $+10 \mathrm{~g}$ phosphorein gave the highest plant dry weight of 11.54 and 15.23 gfollowed by $5 \mathrm{~g}$ nitrobein $+5 \mathrm{~g}$ phosphorein (10.78 and $14.49 \mathrm{~g}$ in the first and second seasons, respectively). That could be attributed to effect of biofertilizers on plant hormones creation, improving phosphorus solubilization and nutrient mobilization and hence increasing plant growth (Rashed et al.,2017) on Nigella sativa. The present results are in agreement with those obtained by Eid and El-Gawwas(2002) on marjoram, Hassan et al.(2015)on Rosmarinus officinalis.

Considering the second order interaction effect, results presented in Table (3) demonstrated that gibberillic acid and biofertilizers application, generally increased plant total dry weight, especially with increasing salinity levels up to $6 \mathrm{dSm}-1$ in the two seasons. That might be due to gibberillic acid effect on cell enlargement under salt stress (Achard et al.,2006), however biofertilizer promote salinity tolerance by enhancing nutrient acquisition and maintenance of the $\mathrm{K}_{+}: \mathrm{Na}+$ ratio (Smith and Read,2008) and altering the hormonal profiles (Aroca et al.,2013). The present results are in agreement with those were obtained by Ali and Hassan (2012) on Matricaria chamomilla and Rashed et al.(2017) on Nigella sativa. 
Table (4):Effect of water salinity, $\mathrm{GA}_{3}$, biofertilizer and their interactions on total dry weight / plant $(g)$ of Matricaria chamomilla L. plants in the seasons of 2016 and 2017.

\begin{tabular}{|c|c|c|c|c|c|c|c|}
\hline \multirow{3}{*}{$\begin{array}{l}\text { Water } \\
\text { Salinity } \\
\text { (A) } \\
\text { dSm-1 }\end{array}$} & \multirow{3}{*}{$\begin{array}{c}\text { GA3 } \\
\text { (B) } \\
m g ~ L-1\end{array}$} & \multicolumn{3}{|c|}{$\begin{array}{l}\text { First season } \\
(2015 \text { / 2016) }\end{array}$} & \multicolumn{3}{|c|}{$\begin{array}{l}\text { Second season } \\
(2016 / 2017)\end{array}$} \\
\hline & & \multicolumn{3}{|c|}{ Biofertilizer(C) } & \multicolumn{3}{|c|}{ Biofertilizer(C) } \\
\hline & & B0 & B1 & $\mathrm{B} 2$ & B0 & B1 & $\mathrm{B} 2$ \\
\hline \multirow{3}{*}{ TW } & 0 & 12.76 & 11.48 & 11.15 & 14.04 & 14.28 & 14.62 \\
\hline & 100 & 11.66 & 13.64 & 10.10 & 14.34 & 15.24 & 16.45 \\
\hline & 200 & 9.80 & 10.69 & 14.23 & 16.32 & 14.69 & 17.59 \\
\hline \multirow{3}{*}{3} & 0 & 9.01 & 10.13 & 11.81 & 14.59 & 12.44 & 11.52 \\
\hline & 100 & 10.51 & 10.22 & 13.56 & 15.19 & 16.05 & 16.78 \\
\hline & 200 & 10.10 & 9.44 & 9.84 & 15.69 & 14.93 & 16.77 \\
\hline \multirow{3}{*}{6} & 0 & 9.61 & 9.84 & 10.71 & 11.38 & 11.38 & 10.11 \\
\hline & 100 & 9.97 & 10.14 & 10.20 & 16.05 & 12.40 & 12.70 \\
\hline & 200 & 10.37 & 11.45 & 12.25 & 13.00 & 15.72 & 17.57 \\
\hline \multicolumn{2}{|c|}{ TW } & 11.40 & 11.93 & 11.82 & 14.90 & 14.73 & 16.22 \\
\hline \multirow{2}{*}{\multicolumn{2}{|c|}{$\begin{array}{l}3 \\
6\end{array}$}} & 9.87 & 9.93 & 11.74 & 15.15 & 14.47 & 15.02 \\
\hline & & 9.98 & 10.47 & 11.05 & 13.41 & 13.17 & 13.46 \\
\hline \multicolumn{2}{|c|}{ GA3 0} & 10.46 & 10.48 & 11.22 & 12.70 & 13.27 & 12.08 \\
\hline \multicolumn{2}{|c|}{100} & 10.71 & 11.33 & 11.28 & 14.56 & 15.19 & 15.30 \\
\hline \multicolumn{2}{|c|}{200} & 10.08 & 10.52 & 12.10 & 15.11 & 15.00 & 18.31 \\
\hline \multirow{2}{*}{\multicolumn{2}{|c|}{ W.S.x GA3 }} & 0 & 100 & 200 & 0 & 100 & 200 \\
\hline & & $\mathrm{mg} \mathrm{L}-1$ & $\mathrm{mg} \mathrm{L}-1$ & $\mathrm{mg} \mathrm{L}-1$ & $\mathrm{mg} \mathrm{L-1}$ & mg L-1 & $\mathrm{mg} \mathrm{L}-1$ \\
\hline \multicolumn{2}{|c|}{ TW } & 11.79 & 11.80 & 11.57 & 14.31 & 15.34 & 16.20 \\
\hline \multicolumn{2}{|c|}{3} & 10.31 & 11.43 & 9.79 & 12.85 & 16.00 & 15.79 \\
\hline \multicolumn{2}{|l|}{6} & 10.05 & 10.10 & 11.35 & 10.49 & 13.71 & 16.43 \\
\hline \multirow{2}{*}{\multicolumn{2}{|c|}{ W.S }} & T.W. & 3dsm-1 & $6 \mathrm{dsm}-1$ & T.W. & $3 \mathrm{dsm}-1$ & $6 \mathrm{dsm}-1$ \\
\hline & & 11.72 & 10.51 & 10.50 & 15.28 & 14.88 & 13.68 \\
\hline \multirow{3}{*}{\multicolumn{2}{|c|}{ GA3 }} & 0 & 100 & 200 & 0 & 100 & 200 \\
\hline & & $\mathrm{mg} \mathrm{L}-1$ & mg L-1 & $\mathrm{mg} \mathrm{L}-1$ & mg L-1 & mg L-1 & mg L-1 \\
\hline & & 10.72 & 11.11 & 11.90 & 12.68 & 15.02 & 16.14 \\
\hline \multirow{2}{*}{\multicolumn{2}{|c|}{ Bio }} & B0 & B1 & B2 & B0 & B1 & B2 \\
\hline & & 10.42 & 10.78 & 11.54 & 14.12 & 14.49 & 15.23 \\
\hline \multicolumn{5}{|c|}{$\begin{array}{ll}\text { L.S.D } 0.05 & \\
A=1.20 & B=0.70 \\
C=0.78 & A \times B=1.22 \\
A \times C=1.36 & B \times C=1.36 \\
A \times B \times C=2.35 & \end{array}$} & $\begin{array}{l}A=1.23 \\
C=0.75 \\
A \times C=0.91 \\
A \times B \times C=\end{array}$ & \multicolumn{2}{|c|}{$\begin{array}{c}B=1.37 \\
A \times B=2.38 \\
B \times C=0.91 \\
2.25\end{array}$} \\
\hline
\end{tabular}




\section{Flower yield characteristics:}

\subsection{Number of flower heads (inflorescences) per plant.}

Results presented in Table (5) revealed that number of flower heads per chamomile was significantly affected by the three studied factors, i.e. salinity levels of irrigation water, gibberillic acid concentrations and biofertilizer rates besides all the two and three factors interactions in the two seasons. Increasing salinity levels to $6 \mathrm{dSm}-1$ gradually decreased the number of flower heads by 80.03 and 137.73 heds / plant in the first and second seasons, respectively, that could be due to the adverse effect of salinity on number of branches/ plant (Ali and Hassan, 2012) on Matricaria chamomilla. These results agreed with those reported by Kamkari et al.(2016) on pot marigold. With regard to GA3 effect, obtained results showed that increasing concentration up to $100 \mathrm{mg} \mathrm{L}$ 1produced the highest number of flower heads/ plant 444.51 - 504.69 in seasons 2016 and 2017, respectively. These results agree with those were reported by Amiri et al.(2014) on Matricaria recutita and Palei et al. (2016) on African marigold. Biofertilizer application significantly increased by 19.16 and 33.66 heads with $5 \mathrm{~g}$ nitrobein $+5 \mathrm{~g}$ phosphorein and $10 \mathrm{~g}$ nitrobein $+10 \mathrm{~g}$ phosphorein in the first season and 97.65 and 59.97 heads, respectively, in the second season over than the control. Positive effect of biofertilizer could be due to plant hormone creation, phosphorus solubilization and nutrient mobilization (Rashed et al., 2017) on Nigella sativa. These findings are in agreement with those of Mashhadi et al. (2017) on chamomile. Concerning the three factors interaction effect on number of flower heads/ plant, results presented in Table (5) showed that the highest number of flower heads 614.83 and 629.67 resulted from $10 \mathrm{~g}$ nitrobein + $10 \mathrm{~g}$ phosphorein biofertilizer application without or with $100 \mathrm{mg} \mathrm{L}-1 \mathrm{GA3}$ under irrigation with tap water, respectively, besides $100 \mathrm{mg} \mathrm{L}-1$ gibberillic acid combined with $5 \mathrm{~g}$ nitrobein $+5 \mathrm{~g}$ phosphorein / pot under irrigation with saline water (EC, $6 \mathrm{dsm}$ 1). However, the highest number of flower heads /plant under irrigation with tap water and $10 \mathrm{~g}$ nitrobein $+10 \mathrm{~g}$ phosphorein /pot 605.10 and 648.29 at 0 and $100 \mathrm{mg} \mathrm{L}-1 \mathrm{GA} 3$, respectively, and 669.65 and 616.94 flower under $5 \mathrm{~g}$ nitrobein + $5 \mathrm{~g}$ phosphorein and 100 and $200 \mathrm{mg} \mathrm{L}-1 \mathrm{GA3}$, respectively. Besides 622.64 and 708.41 flower heads that resulted under saline water (EC, $3 \mathrm{dsm}-1$ ), fertilization with $5 \mathrm{~g}$ nitrobein $+5 \mathrm{~g}$ phosporein with $100 \mathrm{mg} \mathrm{L}-1$ GA3. These results clearly showed the biofertilizers and GA3 effect on nutrient mobilization, hormone creation. Also, the development flower primordial was greatly, influenced by growth regulators (Kumar et al, 2010). 
Table (5) Effect of water salinity, GA3, biofertilizer and their interactions on number of flowers head / plant of Matricaria chamomilla $L$.

\begin{tabular}{|c|c|c|c|c|c|c|c|}
\hline \multirow{3}{*}{$\begin{array}{l}\text { Water } \\
\text { Salinity } \\
\text { (A) } \\
\text { dSm-1 }\end{array}$} & \multirow{3}{*}{$\begin{array}{c}\text { GA3 } \\
\text { (B) } \\
m g ~ L-1\end{array}$} & \multicolumn{3}{|c|}{$\begin{array}{l}\text { First season } \\
(2015 \text { / 2016) }\end{array}$} & \multicolumn{3}{|c|}{$\begin{array}{c}\text { Second season } \\
(2016 / 2017)\end{array}$} \\
\hline & & \multicolumn{3}{|c|}{ Biofertilizer(C) } & \multicolumn{3}{|c|}{ Biofertilizer(C) } \\
\hline & & B0 & B1 & B2 & B0 & B1 & B2 \\
\hline \multirow{3}{*}{ TW } & 0 & 385.50 & 497.83 & 614.83 & 574.47 & 402.90 & 605.10 \\
\hline & 100 & 426.00 & 436.67 & 629.67 & 571.26 & 669.65 & 648.29 \\
\hline & 200 & 462.83 & 419.83 & 502.00 & 357.84 & 616.94 & 307.83 \\
\hline \multirow{3}{*}{3} & 0 & 441.33 & 331.17 & 440.33 & 341.98 & 622.64 & 489.67 \\
\hline & 100 & 432.33 & 366.17 & 382.67 & 308.43 & 708.41 & 574.20 \\
\hline & 200 & 382.50 & 440.67 & 489.33 & 525.17 & 486.15 & 417.89 \\
\hline \multirow{3}{*}{6} & 0 & 373.17 & 470.33 & 489.83 & 246.94 & 573.05 & 312.28 \\
\hline & 100 & 440.67 & 572.83 & 313.67 & 326.46 & 235.49 & 500.05 \\
\hline & 200 & 343.33 & 324.67 & 326.33 & 522.45 & 338.61 & 459.40 \\
\hline \multicolumn{2}{|c|}{ TW } & 424.77 & 451.44 & 582.16 & 501.19 & 563.16 & 520.40 \\
\hline \multicolumn{2}{|c|}{3} & 418.72 & 379.33 & 437.38 & 391.86 & 605.73 & 493.92 \\
\hline \multicolumn{2}{|c|}{6} & 385.72 & 455.94 & 376.61 & 365.28 & 382.38 & 423.91 \\
\hline \multicolumn{2}{|c|}{ GA3 O } & 400.00 & 433.11 & 448.99 & 387.79 & 532.86 & 469.01 \\
\hline \multicolumn{2}{|c|}{100} & 433.00 & 458.55 & 442.00 & 402.05 & 537.84 & 574.18 \\
\hline \multicolumn{2}{|c|}{200} & 396.22 & 395.05 & 439.22 & 468.48 & 480.56 & 395.03 \\
\hline \multicolumn{2}{|c|}{ W.S. $\times$ GA3 } & $\begin{array}{c}0 \\
m g ~ L-1\end{array}$ & $\begin{array}{c}100 \\
m g ~ L-1\end{array}$ & $\begin{array}{c}200 \\
m g ~ L-1\end{array}$ & $\begin{array}{c}0 \\
m g ~ L-1\end{array}$ & $\begin{array}{c}100 \\
m g ~ L-1\end{array}$ & $\begin{array}{c}200 \\
\mathrm{mg} \mathrm{L}-1\end{array}$ \\
\hline \multicolumn{2}{|c|}{ TW } & 499.38 & 497.44 & 461.55 & 527.48 & 629.73 & 427.53 \\
\hline \multicolumn{2}{|c|}{3} & 404.28 & 393.72 & 437.44 & 629.73 & 530.35 & 476.40 \\
\hline \multicolumn{2}{|c|}{6} & 444.44 & 442.38 & 331.44 & 427.53 & 476.40 & 440.15 \\
\hline \multirow{2}{*}{\multicolumn{2}{|c|}{ W.S }} & T.W. & 3dsm-1 & $6 \mathrm{dsm}-1$ & T.W. & 3 dsm-1 & $6 \mathrm{dsm}-1$ \\
\hline & & 486.12 & 411.81 & 406.09 & 528.25 & 497.17 & 390.52 \\
\hline \multirow{3}{*}{\multicolumn{2}{|c|}{ GA3 }} & 0 & 100 & 200 & 0 & 100 & 200 \\
\hline & & $\mathrm{mg} \mathrm{L}-1$ & $m g ~ L-1$ & $\mathrm{mg} \mathrm{L}-1$ & $\mathrm{mg} \mathrm{L}-1$ & mg L-1 & $\mathrm{mg} \mathrm{L}-1$ \\
\hline & & 427.36 & 444.51 & 410.16 & 463.22 & 504.69 & 448.03 \\
\hline \multirow{2}{*}{\multicolumn{2}{|c|}{ Bio }} & B0 & B1 & B2 & B0 & B1 & B2 \\
\hline & & 409.74 & 428.90 & 443.40 & 419.44 & 517.09 & 479.41 \\
\hline \multicolumn{2}{|c|}{$\begin{array}{l}\text { L.S.D } 0.05 \\
A=44.59 \\
C=19.76 \\
A \times C=34.23 \\
A \times B \times C=59.29\end{array}$} & $\begin{array}{l}B=31.50 \\
A \times B=54.57 \\
B \times C=34.23\end{array}$ & & & \multicolumn{3}{|c|}{$\begin{array}{l}A=34.43 \quad B=27.81 \\
C=38.58 \quad A \times B=47.83 \\
A \times C=66.90 \quad B \times C=66.90 \\
A \times B \times C=115.87\end{array}$} \\
\hline
\end{tabular}

plants in the seasons of 2016 and 2017. 


\subsection{Fresh weight of flower heads yield (g/plant).}

Results presented in Table (6) revealed that fresh weight of flower heads yield per chamomile plant was significantly affected by salinity levels of irrigation water, GA3 and biofertilizer application besides all second and three factors interactions in 2016 and 2017 growing seasons. Increasing salinity stress up to EC, 3 and $6 \mathrm{dSm}-1$ led to significantly decreased in fresh weight of flower heads yield / plant by 20.90 and $28.40 \%$, respectively, compared with irrigation with nonsaline water in the first season. However, these percentages were 14.59 and $27.64 \%$, respectively, in the second season. These reactions could be due to the adverse effects of salinity stress on apical growth of chamomile plants and endogenous hormonal imbalance, besides sometimes it could be due to the lethal effects of $\mathrm{Na}+$ and $\mathrm{Cl}-$ ions or adverse water relations (Younis et al.,2010). These results are in agreement with those of Kamkari et al.(2016) on pot marigold. Concerning gibberillic acid effect, the results indicated that $100 \mathrm{mg} \mathrm{L}-1$ GA3 produced the highest flower heads fresh weight per chamomile plant(42.60 and $47.57 \mathrm{~g} /$ plant) in seasons of 2016 and 2017, respectively, with insignificant difference without GA3 in the first season. Conversely, the highest GA3 concentration (200 mg L-1) produced the lowest flower heads yields of 37.01 and $36.08 \mathrm{~g} /$ plant in the first and second seasons, respectively, that might be due to gibberillic acid stimulation effect on the vegetative growth, mainly (Khan et al. ,2015). These results are in harmony with results of Reda et al. (2010) on Chamomile recutita. .

Results in Table (6), also revealed that fresh weight of flower heads yield per chamomile plant enhanced progressively with increasing biofertilizer levels from 0 to $10 \mathrm{~g}$ nitrobein $+10 \mathrm{~g}$ phosphorein per pot. The maximum fresh flowers yield / plant was 45.48 and $47.71 \mathrm{~g}$ in the first and second seasons, respectively, resulted from $10 \mathrm{~g}$ nitrobein $+10 \mathrm{~g}$ phosphorein / pot. That might be due to that biofertilizers enhanced the vegetative growth and consequently number of branches / plant will increased (Cohen et al. ,2007). These results are in line with those reported by Ali (2001) on Calendula officinallis and Mashhadi et al.(2017) on chamomile. With respect to the second order interaction effect on that trait, obtained results pointed out that irrigation chamomile with nonsaline water and high biofertilizer level(10 g nitrobein +10 $\mathrm{g}$ phosporein /pot) without giberrillic acid spraying or spraying GA3with $100 \mathrm{mg}$ L-1 produced the highest fresh flower heads yield per plant 70.36 and 69.25 $\mathrm{g}$, respectively, in the first season and 76.78 and72.75g. in the second season. 
Table (6):Effect of water salinity, GA3, biofertilizer and their interactions on total fresh weight of flowers head yield ( $g /$ plant) of Matricaria

\begin{tabular}{|c|c|c|c|c|c|c|c|}
\hline \multirow{3}{*}{$\begin{array}{l}\text { Water } \\
\text { Salinity } \\
(A) \\
\text { dSm-1 }\end{array}$} & \multirow{3}{*}{$\begin{array}{c}\text { GA3 } \\
\text { (B) } \\
\text { mg L-1 }\end{array}$} & \multicolumn{3}{|c|}{$\begin{array}{l}\text { First season } \\
(2015 \text { / 2016) }\end{array}$} & \multicolumn{3}{|c|}{$\begin{array}{c}\text { Second season } \\
(2016 / 2017)\end{array}$} \\
\hline & & \multicolumn{3}{|c|}{ Biofertilizer(C) } & \multicolumn{3}{|c|}{ Biofertilizer(C) } \\
\hline & & B0 & B1 & B2 & B0 & B1 & B2 \\
\hline \multirow{3}{*}{$\mathrm{TW}$} & 0 & 47.57 & 36.07 & 70.36 & 48.65 & 36.87 & 76.78 \\
\hline & 100 & 50.80 & 45.61 & 69.25 & 35.50 & 58.48 & 72.75 \\
\hline & 200 & 38.34 & 40.23 & 45.15 & 39.92 & 38.64 & 39.16 \\
\hline \multirow{3}{*}{3} & 0 & 32.62 & 53.25 & 35.67 & 39.78 & 58.96 & 39.93 \\
\hline & 100 & 27.52 & 40.09 & 40.35 & 21.18 & 50.25 & 61.57 \\
\hline & 200 & 37.53 & 38.71 & 44.90 & 43.02 & 33.93 & 32.95 \\
\hline \multirow{3}{*}{6} & 0 & 42.79 & 33.79 & 42.87 & 21.36 & 49.73 & 26.58 \\
\hline & 100 & 37.99 & 40.31 & 31.54 & 53.79 & 21.36 & 53.31 \\
\hline & 200 & 22.29 & 36.71 & 29.25 & 42.91 & 27.90 & 26.36 \\
\hline \multicolumn{2}{|c|}{ TW } & 45.57 & 40.63 & 61.58 & 41.35 & 44.66 & 62.89 \\
\hline \multicolumn{2}{|c|}{3} & 32.56 & 44.01 & 40.30 & 34.66 & 47.71 & 44.82 \\
\hline \multicolumn{2}{|c|}{6} & 34.35 & 36.93 & 34.55 & 39.35 & 32.99 & 35.41 \\
\hline \multicolumn{2}{|c|}{ GA3 0} & 40.99 & 41.03 & 49.63 & 36.59 & 48.52 & 47.76 \\
\hline \multicolumn{2}{|c|}{100} & 38.77 & 42.00 & 47.04 & 36.82 & 43.36 & 62.54 \\
\hline \multicolumn{2}{|c|}{200} & 32.72 & 38.54 & 39.76 & 41.95 & 33.49 & 32.82 \\
\hline \multicolumn{2}{|c|}{ W.S. $\times$ GA3 } & $\begin{array}{c}0 \\
m g ~ L-1\end{array}$ & $\begin{array}{c}100 \\
m g ~ L-1\end{array}$ & $\begin{array}{c}200 \\
\mathrm{mg} \mathrm{L}-1\end{array}$ & $\begin{array}{c}0 \\
\mathrm{mg} \mathrm{L}-1\end{array}$ & $\begin{array}{c}100 \\
\mathrm{mg} \mathrm{L}-1\end{array}$ & $\begin{array}{c}200 \\
m g ~ L-1\end{array}$ \\
\hline \multicolumn{2}{|c|}{ T.W } & 51.33 & 55.22 & 41.24 & 54.10 & 55.57 & 39.24 \\
\hline \multicolumn{2}{|c|}{3} & 40.51 & 35.98 & 40.38 & 46.22 & 44.33 & 36.63 \\
\hline \multicolumn{2}{|c|}{6} & 39.81 & 36.61 & 29.41 & 32.55 & 42.82 & 32.39 \\
\hline \multirow{2}{*}{\multicolumn{2}{|c|}{ W.S }} & T.W. & 3dsm-1 & $6 \mathrm{dsm}-1$ & T.W. & $3 \mathrm{dsm}-1$ & $6 \mathrm{dsm}-1$ \\
\hline & & 49.26 & 38.69 & 35.27 & 49.63 & 42.39 & 35.91 \\
\hline \multirow{3}{*}{\multicolumn{2}{|c|}{ GA3 }} & 0 & 100 & 200 & 0 & 100 & 200 \\
\hline & & $\mathrm{mg} \mathrm{L}-1$ & $\mathrm{mg} \mathrm{L}-1$ & $\mathrm{mg} \mathrm{L}-1$ & $\mathrm{mg} \mathrm{L}-1$ & $\mathrm{mg} \mathrm{L}-1$ & $\mathrm{mg} \mathrm{L}-1$ \\
\hline & & 43.88 & 42.60 & 37.01 & 44.29 & 47.57 & 36.08 \\
\hline \multirow{2}{*}{\multicolumn{2}{|c|}{ Bio }} & B0 & B1 & B2 & B0 & B1 & B2 \\
\hline & & 37.49 & 40.52 & 45.48 & 38.45 & 41.79 & 47.71 \\
\hline \multicolumn{5}{|c|}{$\begin{array}{ll}\text { L.S.D } 0.05 & \\
A=2.92 & B=3.96 \\
C=2.81 & A \times B=6.86 \\
A \times C=4.87 & B \times C=4.87 \\
A \times B \times C=8.44\end{array}$} & $\begin{array}{l}A=2.39 \\
C=2.88 \\
A \times C=5.0 \\
A \times B \times C=\end{array}$ & \multicolumn{2}{|c|}{$\begin{array}{l}B=2.75 \\
A \times B=4.78 \\
B \times C=5.00 \\
67\end{array}$} \\
\hline
\end{tabular}

chamomilla L. plants in the seasons of 2016 and 2017. 


\subsection{Dry weight of flower head (yield)(g/plant).}

Presented data in Table (7) indicated that salinity levels of irrigation water, gibberillic acid concentrations, biofertilizer application levels and their interactions between the three studied factors had significant effects on dry weight of flower head yield/plant in the two growing seasons. Irrigated chamomile plants with fresh water produced significantly highest dry weight of flower head yields 17.37 and $18.22 \mathrm{~g} /$ plant in the first and second seasons, respectively. On the other hand, increasing salinity levels of irrigations water up to EC, 3 and 6 dsm-1 significantly decreased dry weight of flower head yields per plant by 29.19 and $35.0 \%$, respectively, in the first season and 33.10 and $37.05 \%$ in the second season, but the differences between the two salinity levels did not reach significance level. These might be due to the adverse effects of saline stress on apical growth of chamomile plant and imbalance of endogenous hormones (Younis et al.,2010).Similar results were obtained by Dadkhah(2010) on Matricaria chamomilla, Mogahdam et al.(2014)on Matricaria recutita, Kamkari et al.(2016) on pot marigold. With regard to giberrillic acid concentrations effects, results showed that $100 \mathrm{mg} \mathrm{L}$-1application produced the highest dry weight of flower head yield 13.84 and $15.62 \mathrm{~g} /$ plant in seasons of 2016 and 2017, respectively, however this GA3 concentration was statistically equaled without GA3 spraying $14.45 \mathrm{~g} /$ plant in the first season. It may be because GA3 in salt stressed plants showed an increase in photosynthetic capacitya vital factor for higher dry matter synthesis ( Misratia et al.2013). These findings agree with those reported by Reda et al. (2010) on Chamomile recutita and Palei et al. (2016) on African marigold. With respect to biofertilization effect, results presented in Table (7) cleared that the highest dry weight of flower heads yield was 14.67 and $15.15 \mathrm{~g} /$ plant resulted from application the highest biofertilizer rate $(10 \mathrm{~g}$ nitrobein $+10 \mathrm{~g}$ phosphorein $/ \mathrm{pot})$ in the first and second seasons, respectively. That might be due the enhancement effect of biofertilizers on vegetative growth and consequently increased number of branches per plant (Cohen et al.,2007). These results agree with those reported by Ali (2001) on Calendula officinallis, Mashhadi et al.(2017) and Mostafa et al.(2019) on chamomile.

Considering the interaction between the three studied factors on dry weight of flower heads yield per chamomile plant in the two growing seasons, obtained results indicated that irrigation of chamomile plants with fresh water, spraying with $100 \mathrm{mg} \mathrm{L-1giberrillic}$ acid and biofertilized with $10 \mathrm{~g}$ nitrobein +10 $\mathrm{g}$ phosporein / pot produced the highest dry weight of flower heads yield of 24.03 and $25.24 \mathrm{~g} /$ plant in the first and second seasons, respectively, besides 5 $\mathrm{g}$ nitrobein $+5 \mathrm{~g}$ phosporein combined with $100 \mathrm{mg} \mathrm{L}-1 \mathrm{GA} 323.89 \mathrm{~g} / \mathrm{plant}$ and10 g nitrobein + $10 \mathrm{~g}$ phosphorein without GA3 application $23.52 \mathrm{~g} / \mathrm{plant}$ under irrigation with fresh water in the second season. 
Table (7):Effect of water salinity, GA3, biofertilizer and their interactions on total dry weight of flowers head yield (g/plant) of Matricaria chamomilla L. plants in the seasons of 2016 and 2017.

\begin{tabular}{|c|c|c|c|c|c|c|c|}
\hline \multirow{3}{*}{$\begin{array}{c}\text { Water } \\
\text { Salinity } \\
\text { (A) } \\
\text { dSm-1 }\end{array}$} & \multirow{3}{*}{$\begin{array}{c}\text { GA3 } \\
\text { (B) } \\
\text { mg L-1 }\end{array}$} & \multicolumn{3}{|c|}{$\begin{array}{l}\text { First season } \\
(2015 \text { / 2016) }\end{array}$} & \multicolumn{3}{|c|}{$\begin{array}{c}\text { Second season } \\
(2016 / 2017)\end{array}$} \\
\hline & & \multicolumn{3}{|c|}{ Biofertilizer(C) } & \multicolumn{3}{|c|}{ Biofertilizer(C) } \\
\hline & & B0 & B1 & B2 & B0 & B1 & B2 \\
\hline \multirow{3}{*}{$\mathrm{TW}$} & 0 & 17.43 & 15.26 & 16.57 & 13.48 & 11.16 & 23.52 \\
\hline & 100 & 15.50 & 15.52 & 24.03 & 20.68 & 23.89 & 25.24 \\
\hline & 200 & 16.77 & 17.25 & 18.04 & 17.91 & 12.55 & 15.66 \\
\hline \multirow{3}{*}{3} & 0 & 10.00 & 14.40 & 21.56 & 11.83 & 15.77 & 11.56 \\
\hline & 100 & 13.96 & 15.89 & 9.58 & 5.88 & 13.49 & 17.73 \\
\hline & 200 & 11.16 & 6.66 & 7.53 & 13.83 & 10.27 & 9.42 \\
\hline \multirow{3}{*}{6} & 0 & 15.83 & 8.73 & 10.32 & 11.02 & 17.73 & 10.27 \\
\hline & 100 & 11.14 & 7.39 & 11.61 & 10.87 & 6.68 & 16.20 \\
\hline & 200 & 12.44 & 11.36 & 12.83 & 12.13 & 11.55 & 6.78 \\
\hline \multicolumn{2}{|c|}{ T.W. } & 16.56 & 16.00 & 19.54 & 17.35 & 15.86 & 21.47 \\
\hline \multicolumn{2}{|c|}{3} & 11.70 & 12.31 & 12.88 & 10.51 & 13.17 & 12.90 \\
\hline \multicolumn{2}{|c|}{6} & 13.13 & 9.16 & 11.59 & 11.34 & 11.98 & 11.08 \\
\hline \multicolumn{2}{|c|}{ GA3 0} & 14.42 & 12.79 & 16.15 & 12.11 & 14.88 & 15.11 \\
\hline \multicolumn{2}{|c|}{100} & 13.53 & 12.93 & 15.07 & 12.47 & 14.68 & 19.72 \\
\hline \multicolumn{2}{|c|}{200} & 13.45 & 11.75 & 12.80 & 14.62 & 11.45 & 10.62 \\
\hline \multicolumn{2}{|c|}{ W.S. $\times$ GA3 } & $\begin{array}{c}0 \\
m g ~ L-1\end{array}$ & $\begin{array}{c}100 \\
\mathrm{mg} \mathrm{L}-1\end{array}$ & $\begin{array}{c}200 \\
m g ~ L-1\end{array}$ & $\begin{array}{c}0 \\
m g ~ L-1\end{array}$ & $\begin{array}{c}100 \\
m g ~ L-1\end{array}$ & $\begin{array}{c}200 \\
m g ~ L-1\end{array}$ \\
\hline \multicolumn{2}{|c|}{ T.W } & 16.42 & 18.38 & 17.35 & 16.05 & 23.27 & 15.37 \\
\hline \multicolumn{2}{|c|}{3} & 15.31 & 13.14 & 8.44 & 13.50 & 12.36 & 11.17 \\
\hline \multicolumn{2}{|c|}{6} & 11.62 & 10.04 & 12.21 & 13.00 & 11.24 & 10.15 \\
\hline \multirow{2}{*}{\multicolumn{2}{|c|}{ W.S }} & T.W. & $3 \mathrm{dsm}-1$ & $6 \mathrm{dsm}-1$ & T.W. & $3 \mathrm{dsm}-1$ & $6 \mathrm{dsm}-1$ \\
\hline & & 17.37 & 12.30 & 11.29 & 18.22 & 12.19 & 11.47 \\
\hline \multirow{3}{*}{\multicolumn{2}{|c|}{ GA3 }} & 0 & 100 & 200 & 0 & 100 & 200 \\
\hline & & $\mathrm{mg} \mathrm{L}-1$ & $\mathrm{mg} \mathrm{L}-1$ & $\mathrm{mg} \mathrm{L}-1$ & $\mathrm{mg} \mathrm{L}-1$ & $\mathrm{mg} \mathrm{L}-1$ & $\mathrm{mg} \mathrm{L}-1$ \\
\hline & & 14.45 & 13.84 & 12.67 & 14.03 & 15.62 & 12.23 \\
\hline \multirow{2}{*}{\multicolumn{2}{|c|}{ Bio }} & B0 & B1 & B2 & B0 & B1 & B2 \\
\hline & & 13.80 & 12.49 & 14.67 & 13.07 & 13.67 & 15.15 \\
\hline \multicolumn{5}{|c|}{$\begin{array}{ll}\text { L.S.D 0.05 } & \\
A=1.30 & B=0.93 \\
C=0.78 & A \times B=1.62 \\
A \times C=1.62 & B \times C=1.36 \\
A \times B \times C=2.36 & \end{array}$} & $\begin{array}{l}A=0.73 \\
C=0.95 \\
A \times C=1 \\
A \times B \times C\end{array}$ & \multicolumn{2}{|c|}{$\begin{array}{l}B=0.88 \\
A \times B=1.53 \\
B \times C=1.66 \\
.87\end{array}$} \\
\hline
\end{tabular}




\section{Essential oil productivity}

\section{3 .1.Oil percentage (\%).}

Obtained results in Table (8) revealed that oil percentage in chamomile flowers significantly affected by salinity levels of irrigated water, spraying with different concentrations of gibberillic acid and biofertilizer application levels, beasides their interactions in the growing seasons. Oil percentage was positively affected by salinity levels, where it gradually increased by 0.06 and $0.15 \%$ in the first season and 0.05 and $0.09 \%$ in the second season by increasing levels of salinity to EC, 3 and $6 \mathrm{dSm}-1$, respectively, compared with the control treatment. This may be due a positive correlation between the stress level imposed on the cells and the percentage of oil in the tissue. The increased percentage of oil may result from altered oil biosynthesis under stress, and from restriction of leaf area expansion which can result in denser oil glands compared to the non-stressed leaf Morales et al. (1993) suggested that an increase in oil content in some of the salt stressed plants might be attributed to the decline of the primary metabolites due to the salinity effects, causing intermediary products to become available for secondary metabolites synthesis. Salt stress may also affect the essential oil accumulation indirectly through its effects on either net assimilation or the partitioning of assimilate among growth and differentiation processes. These results are in line with those were obtained by Elhindi et al. (2016) on Ocimum basilicum and Estaji et al.(2018) on Satureja hortensis.

Spraying chamomile plants with 100 and $200 \mathrm{mg} \mathrm{L}-1$ gibberillic acid led to an increase in essential oil percentage by 0.04 and $0.11 \%$ in season of 2016 and 0.05 and $0.09 \%$ in season of 2017 , respectively, compared with untreated plants. GA3 application on lavender plants increased the light efficiency and assimilation potential of plants leading to intensified secondary metabolites production and increased volatile oil biosynthesis and storage (Hassanpouraghdam et al. 2011) on Lavandula officinalis Chaix.. Also, it is likely that elevated leaves fresh and dry weight of plants under GA3 application and concomitant increase in assimilation potential led to the suitable interactions of primary and secondary metabolism in favor of essential oil production (Marshner,1995) . The same trend of results have been reported by Sharaf El- Din et al.(2009) on Melissa officinali and Kumar et al. (2012) on Mentha piperita.

Presented results, also indicated that biofertilizer application significantly increased oil percentage in the two studied seasons. The maximum oil percentage 0.53 and $0.56 \%$ in the first and second seasons, respectively, resulted from fertilized plants with $10 \mathrm{~g}$ nitrobein + $10 \mathrm{~g}$ phosphorein / pot. That could be due to the importance of fertilizers for increasing mineral absorbtion and chlorophyll content in plants. The effect of biofertilizer on increasing the essential oil synthesis in the herb might be attributed to their enhancing effect on increasing the uptake of nutrients by plant roots especially phosphorus element as phosphate groupone linked by (ATP). Hence,the biosynthesis of essential oil is dependent on inorganic $P$ content in the plant. These findings are in consistent with those were reported by many authors such as Hassan et al. (2015) on Rosmarinus officinalis and Mostafa et al.(2019) on chamomile. 
Regarding the interaction,i.e. salinity levels, GA3 concentrations and biofertilization rates effect on oil percentages, obtained results showed that the highest percentages of oil was $0.72 \%$ in the first season and $0.68 \%$ in the second season one resulted from spraying $200 \mathrm{mg} \mathrm{L-1giberrillic} \mathrm{acid} \mathrm{combined}$ with $10 \mathrm{~g}$ nitrobein $+10 \mathrm{~g}$ phosphorein /pot under irrigation chamomile plants with saline water ( EC, $6 \mathrm{dSm}-1$ ). Conversely, irrigated chamomile plants with fresh water combined without or with biofertilizer application produced the lowest oil percentages $0.40,0.39$ and $0.41 \%$, respectively, in season of 2016 and $0.42,0.42$ and $0.44 \%$ in season of 2017 .

Table (8) Effect of water salinity, GA3, biofertilizer and their interactions on oil percentage (\%) of Matricaria chamomilla L. plants in the seasons of 2016 and 2017.

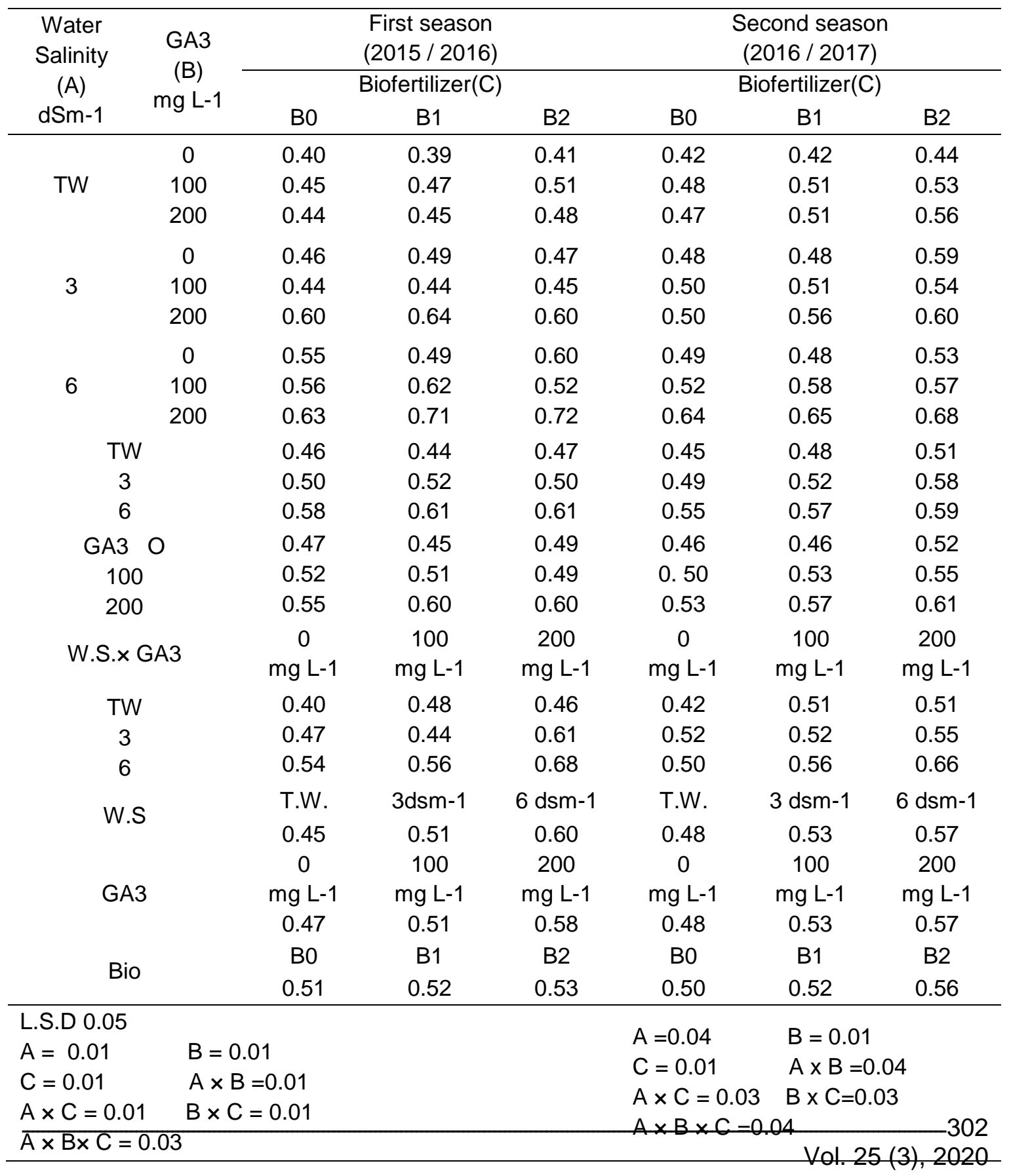




\subsection{Oil yield ( $\mathrm{ml} /$ plant).}

Data presented in Table (9) showed that essential oil yield/plant was significantly affected by three studied factors, i.e. salinity levels of water, gibberillic acid spraying and biofertilizer application, besides their interactions in the two seasons of study.

Increasing salinity levels to EC, $6 \mathrm{dSm}-1$ gradually decreased oil yield/plant by 0.06 and $0.10 \mathrm{ml}$ in season of 2016 and 0.11 and $0.17 \mathrm{ml}$ in season of 2017 as a result of increasing salinity levels up to 3 and $6 \mathrm{dSm}-1$, respectively, compared with fresh water. That could be due to the adverse effect of salinity on nutrient balance,cell division and expansion and consequently on plant growth, as well as a series of metabolic functions (Caia et al.,2014) on Rosa hybrid. The essential oil yield in aromatic plants may be affected positively or negatively by the salinity levels (Neffati et al., 2011) and also by the type and amount of fertilizers and cultivation practices applied (Chrysargyris et al., 2016). Charles et al.(1990) stated the stimulation of essential oil production under salinity could be due to a higher oil gland density and an increase in the absolute number of glands produced prior to leaf emergence. These findings are in consistent with those of Bonacina et al.(2017) on Melissa officinalis.

However, oil yield/plant was significantly increased with increasing giberrillic acid concentrations up to $200 \mathrm{mg} \mathrm{L}-1$ and maximum essential oil yield per chamomile plant 0.23 and $0.26 \mathrm{ml}$ in the first and second seasons, respectively. That might be due to the role of giberrillic acid in leaf expansion and stem elongation (Magome et al.2004).Also,it increased photosynthetic capacity and consequently produced higher growth and dry matter under salt stress. As well as, Hassanpouraghdam et al. (2011) they reported that among phytohormones and plant growth regulators (PGRS) have crucial impact on primary and secondary metabolism of plants. Essential oil production and accumulation of volatile oil bearing plants positively responds to these molecules especially their synthetic ones at external applications and there is strong evidence that, GA3 had constant effects on plants growth and development, and consequently their active principles content and yield. These results are in agreement with Ali and Hassan (2012) on Matricaria chamomilla.

Biofertilizer application to chamomile plants led to gradually increase essential oil yield plant, where $10 \mathrm{~g}$ nitrobein $+10 \mathrm{~g}$ phosporein produced maximum oil yield per plant 0.24 and $0.26 \mathrm{ml}$ in 2016 and 2017 growing seasons, respectively. Carg and Manchanda (2008) on Cajanus cajan, reported that biofertilizers reduce the negative effects of salinity, improve plant growth rate and antioxidant enzyme activities. Also, it could be because of the production of indole acetic acid, gibberellins and some unknown determinants by plant growth-promoting rhizobacteria PGPR, results in increase in root length, root surface area and number of root tips, leading to an enhanced uptake of nutrients thereby improving plant health under stress conditions (Egamberdieva and Kucharova, 2009).These results are in agreement with Mostafa et al. (2019) on chamomile. 
Regarding the three factor interaction between salinity levels plus gibberillic acid spraying $x$ biofertilizer application effect on essential oil yield per chamomile plant in the two studied seasons, results presented in Table(9) showed that application of $10 \mathrm{~g}$ nitrobein $+10 \mathrm{~g}$ phosphorein per plant combined with 100 and $200 \mathrm{mg} \mathrm{L-1gibberillic} \mathrm{acid} \mathrm{under} \mathrm{irrigation} \mathrm{with} \mathrm{fresh}$ water produced the highest oil yield/plant 0.33 and $0.35 \mathrm{ml}$, respectively, in season of 2016 and 0.36 and $0.39 \mathrm{ml}$ in season of 2017, besides $0.34 \mathrm{ml} / \mathrm{plant}$ that resulted from combination between irrigation with fresh water and $10 \mathrm{~g}$ nitrobein $+10 \mathrm{~g}$ phosphorein/pot in the first season. Generally, produced the lowest oil yield per plant with or without gibberillic acid spraying and biofertilizer application in the two seasons. 
Table (9):Effect of water salinity, GA3, biofertilizer and their interactions on oil yield /(ml/plant) of Matricaria chamomilla L. plants in the seasons of 2016 and 2017.

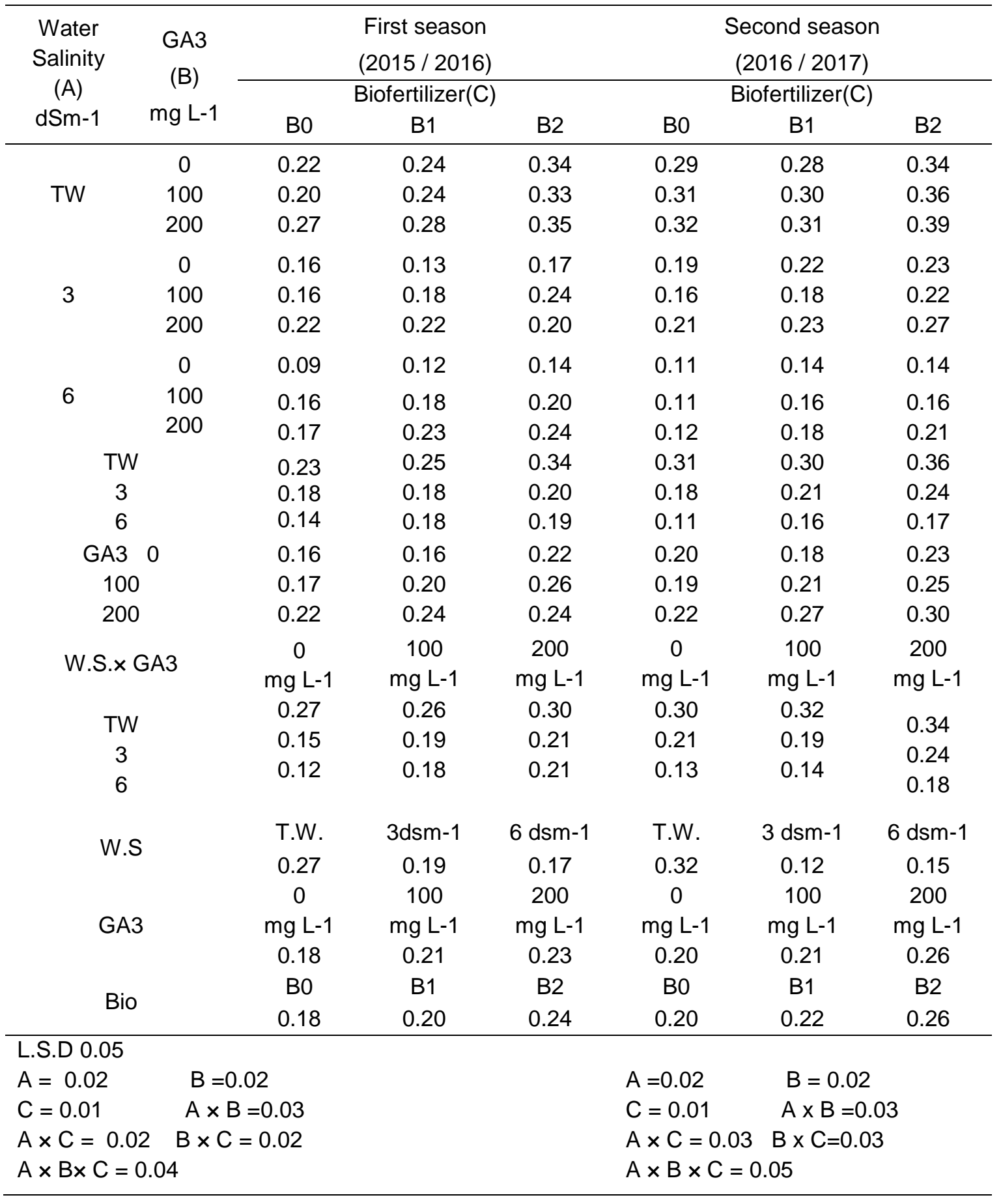




\section{CONCLUSION}

In the conclusion, the results obtained from the present investigation indicated that irrigated chamomile (Matricaria Chamomilla L.) var.(German chamomile) with tap water combined with spraying gibberellic acid three times by (100 and $200 \mathrm{mg} \mathrm{L}-1$ ) and biofertilizer application (nitrobein + phosporein) by $5 \mathrm{~g}$ or $10 \mathrm{~g}$ from both components per pot realized the maximum vegetative and flowering growth and oil yield. However, increasing salinity level of irrigated water led to increase oil percentage.

\section{REFERENCES}

Achard,P.,H. Cheng, De Grauwe, L., Decat, J., Schoutteten, H., Mortiz, T.,Van Der Straeten, D., Peng J. and Harberd, N. (2006). Intergration of plant responses to environmentally activated phytohoromonal signals. Science ,31 ,91-94.

Afifi, M.Y.,Ahmed, T. A., and Atyia, N.M. (1998). Effect of some management practices on salinity regime of soils under irrigation with diluted sea-water. Egypt. J. Soil Sci., 38 (1-4)pp: 413 - 423.

Ahmed,A. H. H., Ghalab, A.R.M. , Hussein, O. S. and El-Hefny, A. M.(2011). Effect of gamma rays and salinity on growth and chemical composition of Ambrosia maritima L. Plants. Journal of Radiation Research and Applied Sciences, 4(A), $1139-1162$.

Ahmed, M. and Kibret, M. (2014). Mechanisms and applications of plant growth promoting rhizobacteria: Current perspective Journal of King Saud University - Science, 26, 1-20 .

Ali, A. F. (2001). Response of pot marigold (Calendula officinalis L.) plants to some rock phosphate sources and yeast. $5^{\text {th }}$ Arabian Horticulture Conference,Egypt. PP:31-41.

Ali, E.F., and Hassan,F.A.S.(2012).Alleviatory Effects of Salt Stress by Mycorrhizal Fungi and Gibberellic Acid on Chamomile Plant. International Journal of Science and Research,3(11),109-118.

Amiri, S., Sharafzadeh, S., and Ordookhani, K. (2014). The effect of gibberellic acid and benzyladenine on growth and essential oils of German chamomile. Indian Journal of Fundamental and Applied Life Sciences, 4(1), 186-188.

Aroca,R., Ruiz-Lozano, J.M., Zamarreno, A.M., Paz, J.A., Garcia -Mina, J.M., Pozo, M. J. , and Lopez-Raez, J. A. (2013). Arbuscular mycorrizal symbiosis influences strigolactone production under salinity and alleviates salt stress in lettuce plants. Journal of Plant Physiology, 170,47-55.

Atteya, A. K. G. , and El Gendy, A. E. G.(2018). Growth, flowering and chemical compositions of Tagetes patulaL. plants as affected with naphthalene acetic acid and gibberellic acid. Bioscience Research, 15(2),716-730.

Basalah, M.O., Mohammad, S.(1999). Effect of salinity and plant growth regulators on seed germination of Medicago sativa L. Pakistan Journal of Biological Sciences , 2: 651-653.

Bonacina, C., Trevizan, C. B., Stracieri, J., dos Santos,T. B. d, Gonçalves, J. E., Gazim, Z. C. , and de Souza, S. G. H. (2017). Changes in growth, oxidative metabolism and essential oil composition of lemon balm (Melissa 
officinalis L.) subjected to salt stress. Australian journal of Crop Science, 11(12), 1665-1674.

British, Pharmacopoeia (1963). Determination of Volatile Oil in Drugs. The Pharmaceutical Press, London.

Brunke, E.,J.Hammerschmidt, and G.Schmaus, (1992).Headspace analysis of selected European medicinal plants.In Proceedings of the 12th International Congress of Flavours, Fragrances and Essential Oils, Vienna, Austria,Oct. 4.-8. 1992 (Woidlich, H. \& Buchbauer,G., eds.).Fachzeitschriftenverlags, Vienna, 105-124.

Caia,X.,Niub,G.,Starman,T.,and Hall, C. (2014). Response of six garden roses (Rosa hybrid L. ) to salt stress. Scientia Horticulturae,168,27-32.

Carg,N.and Manchanda ,G.(2008). Effect of arbuscular mycrorrhizal inoculation of salt-induced nodule senescence in Cajanus cajan (pigeonea). Journal of Plant Growth Regulation 27:115-124.

Charles, D. J., Joly, R. J., and Simon, J. E. (1990). Effect of osmotic stress on the essential oil content and composition of peppermint. Phytochemistry, 29, 2837-2840.

Chrysargyris, A., Panayiotou, C., and Tzortzakis, N. (2016). Nitrogen and phosphorus levels affected plant growth, essential oil composition and antioxidant status of lavender plant (Lavandula angustifolia Mill.). Industrial Crops and Products,83, 577-586..

Cohen,A.T., Mariela, P., Ruben, B., and Patricia, P. (2007). Azospirillum brasilense and ABA improve growth in Arabidopsis. International plant growth substances Association 19 th AnnualMeeting, Puerto Vallarta, Mexico -July .

Dadkhah, A. R.(2010). Effect of salt stress on growth and essential oil of Matricaria chamomilla. Research Journal of Biological Sciences, 5 (10),643646.

Deepika, Varshney ,U. K., Sangwan, P., Manogya, Singh, S., and Preeti(2015). Influence of salinity on morpho-physiological characters of german chamomile (Matricaria chamomilla L.). World journal of Pharmacy and Pharmaceutical Sciences, 4(10), 762-775.

Egamberdieva, D., and Kucharova, Z. (2009). Selection for root colonizing bacteria stimulating wheat growth in saline soils. Biology and Fertility of Soils, 45,563-571.

Eid,M.I., and El-Gawwas, E.O.(2002). Study on the responsibility of marjoram plants to biofertilizeres in study soil. Egypt. Journal of Applied Sciences, 17 (3),163-175.

Elhindi, K., Al-Suhaibani, N.A., Sharaf El-Din, A. F., Yakout, S. M., and AlAmri , S. M.(2016). Effect of foliar-applied iron and zinc on growth rate and essen $\neg$ tial oil in Sweet basil (Ocimum basilicum L.) under saline condi-tions. Progress in Nutrition , 18 (3), 288-298.

El-Naggar, A.H.M., Hassan,M.R.A., Shaban,E.H., and Mohamed,M.E.A. (2015). Effect of Organic and Biofertilizers on Growth, Oil Yield and Chemical Composition of the Essential Oil of Ocimum basillicum L. Plants. Alexandria Journal of Agricultural Research, 60(1),1-16.

Estaji, A., Roosta ,H. R., Rezaei, S. A., Hosseini, S. S., and Niknam, F. (2018). Morphological, physiological and phytochemical response of different. 
Journal of Applied Research on Medicinal and Aromatic Aromatic Plants,10,2533.

Franz, Ch., Bauer, R., Carle, R., Tedesco, D., Tubaro, A., and ZitterlEglseer, K.(2005). Study on the assessments of plants/herbs, plant/herb extracts and their naturally or synthetically produced components as additives for use in animalproduction. CFT/EFSA/FEEDAP/2005/01. 155-69

Gewaily,E.M., Fatma, I., El-Hadidy, T., Abd El-Fattah, H.I., and Salem, S.H. (2006).Efficiency of bio- fertilizers, organic and inorganic amendments application on growth and essential oil of marjoram (Majorana hortensis L.) plants grown in sandy and calcareous soils. Zagazig Journal of Agricultural Research, 33, 205-230.

Grgesina,D., Mandic, D., Karuza, M., Klapec, L., and Bockinak, D. (1995). Chemical composition of different parts of Matricaria chamomilla. Prehrambeno-tehnol. Biotehnol. Rev.,33,111-113

Hassan, E.A., Ali, A. F., and El Gohary. A. E. (2015). Enhancement of Growth, Yield and Chemical Constituents of Rosemary (Rosmarinus officinalis, L.) Plants by Application of Compost and Biofertilization Treatments. Middle East Journal of Agriculture Research, 4 (1), 99-111.

Hassanpouraghdam, M.B. , Hajisamadi A.B., and Khalighi A.(2011). Gibberellic Acid Foliar Application Influences Growth, Volatile Oil and Some Physiological Characteristics of Lavender (Lavandula officinalis Chaix.).Romanian Biotechnological Letters, 16 (4),6322-6327.

Heidari, M., and Sarani, S. (2012). Growth, biochemical components and ion content of chamomile (Matricaria chamomilla L.) under salinity stress and iron deficiency. Journal of The Saudi Society of Agricultural Sciences, 11, 37- 42.

Jackson, M.L. 1973. SoilChemical Analysis. Prentic-Hall. Inc. Englewood, Cliffs,U.S.A.

Javid,M.G., Sorooshzadeh, A., Moradi, F., Sanavy, S.A., and Allahdadi, I. (2011). The role of phytohormones in alleviating salt stress in crop plants. Australian Journal of Crop Science, 5, 726-734.

Kamkari ,B., Asgharzadeh, A., and Azimzadeh, M.(2016). Effects of salt stress and salicylic acid on Vegetative and reproductive traits of pot Marigold. Institute of Integrative Omics and Applied Biotechnology Journal,7 (5),34-41.

Khan, A. F., Mujeeb, F., Aha, F., and Farooqui, A.(2015). Effect of plant growth regulators on growth and essential oil content in palmarosa (Cymbopogon martinii).Asian Journal of Pharmaceutical and Clinical Research,8(2),373-376.

Kumar, A. , Mouzzam, H., and Singh, P. (2012). Response of gibberellic acid on growth behaviour and menthol oil yield of Mentha (Mentha piperita, L.). HortFlora Research Spectrum, 1(3), 284-285.

Kumar,R., Mona, R., and Gaur, G.S.(2010). Effect of GA3 and ethrel on growth and flowering of African marigold cv. Pusa Narangi Gainda. Indian Journal of Horticulture (Special Issue) November,362-366.

Kuraishi,S. and Muir,R.M.(1964). The mechanism of gibberellic action in dwarf pea. Plant and Cell Physiology ,5:259.

Magome,H.,Yamaguchi,S.,Hanada,A.,Kamiya,Y. and Odaboi,K.(2004). Dwarf and delayed - flowering 1, anovel Arabidopsis mutant deficient in 
gibberellic biosynthesis because of over expression of a putative AP2 Transcription factor. Plant Journal, 37,720-729.

Mahfouz, S.A.S. , Elkhateeb, M. A. , Ahmed, G. F., and Mohamed, M. A. (2003). Effect of biofertilization on growth and oil production of marjoram (Marjorana hortensis, Moench.), Ph.D. Thesis, Faculty of Agriculture. Cairo University.Egypt.

Mann, C., and Staba, E.J.(2002). The chemistry, pharmacology and commercial formulations of chamomile. In: Craker LE, Simon JE, editors. Herbs, spices and medicinal plants- recent advances in botany, horticulture and pharmacology. USA: Haworth Press Inc, 235-80.

Marshner, H. ,(1995).Mineral nutrition of higher plants. Academic Press, London, UK.

Mashhadi, A. A. , Majd, M. M., Bakhshandeh, A., and Koochekzadeh, A.(2017). Effect of sulfuric acid and biofertilizers on camazulene, essential oil content and quantitative characteristics of Chamomile (Matricaria chamomilla L.). Iranian Journal of Field Crop Science, 48(3), 855-864.

Misratia,K.M.,Ismail, M.R., Hakim, M.A., Musa, M.H., and Puteh, A. (2013). Eeffect of salinity and alleviating role of gibberellic acid $\left(\mathrm{GA}_{3}\right)$ for improving the morphological, physiological and yield traits of rice varieties. Australian Journal of Crop Science,7,1682-1692.

Mogahdam,A., Fathi,A., Lotfi,M., Asadi,K., and Amouzadeh,A. (2014).The analysis of the effect of salinity and ascorbic acidon growth properties of German Chamomile (Chamomile Recutita L). International Research Journal of Applied and Basic Sciences,8(11),1982-1987.

Morales, C., Cusido, R. M., Palazon, J.,\& Bonfill, M. (1993). Tolerance of mint plants to soil salinity. Journal of the Indian Society of Soil Science,44, 184186.

Morsy, A.M.(2003). Effect of irrigation water quality on the soil physical and hydrological properties in western Delta region .Alex. Sei. Exch.24 : 458.

Morteza,M., Ahmad, T., Hassanali, N., Mehran, O.A., and Shamsali, R. (2013). The biological fertilizers effects on the quality yield of Lippia citriodors plant. International Journal of Plant Production,4(5),1006-1012.

Mostafa, A. , Khalafallah, M., Abo Sedera, S., Fathy, H., and Higazy, A. (2019). Different methods of bacterial inoculation on the yield of chamomile blossoms and essential oil. Global Journal of Environmental Science and Management,5(2),237-248.

Neffati, M., Sriti, J., Hamdaoui, G., Kchouk, M. E., and Marzouk, B. (2011). Salinity impact on fruit yield, essential oil composition and antioxidant activities of Coriandrum sativum fruit extracts. Food Chemistry, 124, 221-225.

Neiman, R. H.(1965). Expansion of bean leaves and its suppression by salinity. Plant Physiology.,40, 156-161.

Palei,S.,Das, A.K., and Dash, D.K.(2016). Effect of plant regulators on growth, flowering and yield attributes of African marigold(Tagetes erecta L.).International Education and Research Journal ,2(6),44-45.

Rashed, N., M., Shala , A.Y., and Mahmoud, M.A. (2017).Alleviation of salt stress in Nigella sativa L. by gibberellic acid and rhizobacteria. Alexandria Science Exchange Journal, 38(4),785-799. 
Reda, F., El-Wahed, M. S. A. A., and El-Din, K. M. G. (2010). Effect of acetic acid, gibberellic acid and kinetin on vegetative growth, flowering, essential oil pattern of chamomile plant (Chamomilla recutita L. Rausch). World Journal of Agricultural Sciences, 6(5),595-600.

Saedi,A.G.H., and Al-Rubaiee,F.A.A. (2012). The role of gibberellic acid and npk fertilizer on some growth characteristics and active compound from two varieties of Chamomile. journal of Kerbala University, 7( 2),168-179.

Shalan,M.N., El-Gawwas,E.O., Dessouky,M.M., and Soliman, S.G.L.I. (2001). Effect of sources and levels of phosphorous fertilization on polish chamomile (Matricaria chamomilla L.) Journal of Agricultural Science, Mansoura University,26 (4) ,15-2233.

Sharaf El-din, M.A., Ibrahim, A.Y., and Korkar, H.M.(2009). Lemon balm (Melissa officinalis L.), Effects of gibberellic acid and dry yeast on growth and essential oil yield and composition. Planta Medica, 75(09).

Smith,S.E., and Read, D.J. (2008).Mycorrhizal symbioses, 3 rd ed. Academic Press, UK.

Snedecor, G. and. Cochran , W (1981). Statistical Methods. Seventh Ed., lowa State UnivPress, Amer., lowa, USA.

Tuna, A. L., Kaya, C. , Dikilitas, M. and Higgs, D. (2008).The combined effects of gibberellic acid and salinity on some antioxidant enzyme activities, plant growth parameters and nutritional status in maize plants. Environmental and Experimental Botany, 62,1-9.

Younis,M.E., Hasaneen, M.N.A., and Kazamel, A.M.S. (2010). Exogenously applied ascorbic acid ameliorates detrimental effects of $\mathrm{NaCl}$ and mannitol stress in Vicia faba seedlings. Protoplasma, 239,39-48. 


\section{الملخص العريي}

\section{تأثير ملوحة ماء الرى وحامض الجيبريلليك والأسمدة الحيوية على النمو الخضري والزهري وإنتاج الزيت في نبات الثيح البابونج}

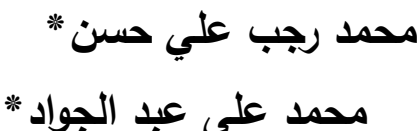

* على حسن النجار

* محمد على عبد الجواد

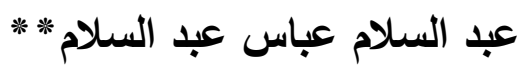

* قسم الزهور ونباتات الزبنة و تتسيق الحدائق ـ كلية الزراعة (الثاطبي) . جامعة الاسكندرية ـ مصر

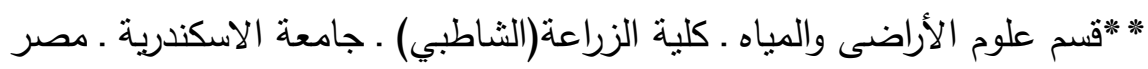

أجري هذا البحث لدراسة تأثثر الملوحة،حمض الجبريلليك والاسمدة الحيوية علي النموالخضرى والزهرى وإنتاج Matricaria chamomilla, L. var. " German الزيت فى نباتات الثيح البابونج الصنف الألمانىى (split-split plot) في ثلاث مكررات chamomile ") وخصصت القطع الرئيسية المتمثلة فى مستويات ملوحة مياة الري (ماء الصنبور ، ب ، 7 ديسيسيمنز/ منر) ،

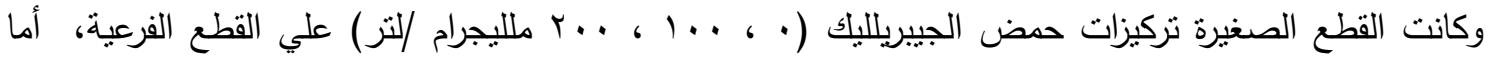

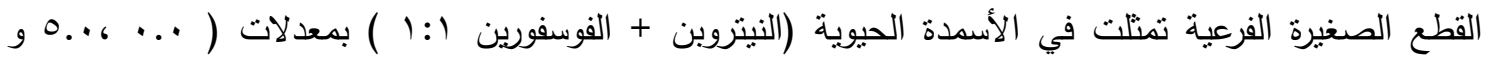

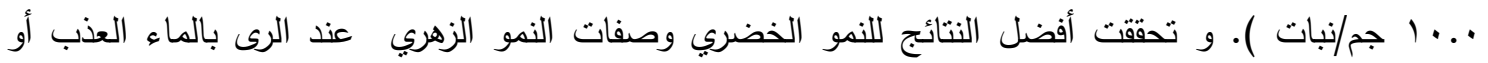

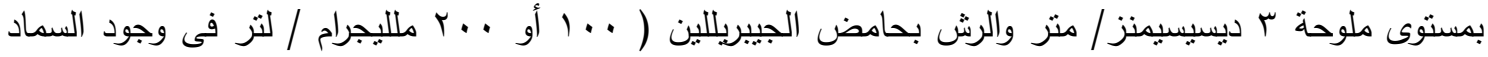
الحيوي عند التركيز ..0 و ... جم/نبات ، وقد تم الحصول على أعلي نسبة زيت فى الأزهار بالري بماء

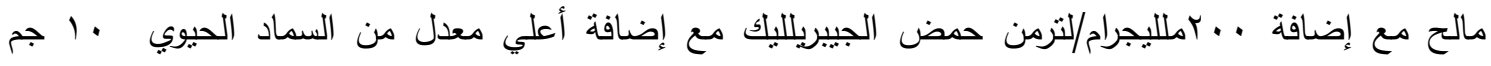
نيتروبين + • (1 جم فوسفورين/ نبات. وتحقق أعلي محصول من الزيت / النبات في كلا الموسمين بالري بماء

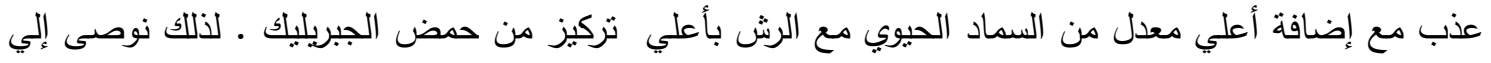

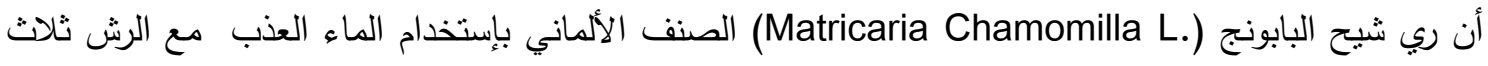
مرات بحمض الجبريليك بتركيز . . أو . . . ملليجرام/لتز والتسميد الحيوي المكون من (النتروبين والفوسفورين)

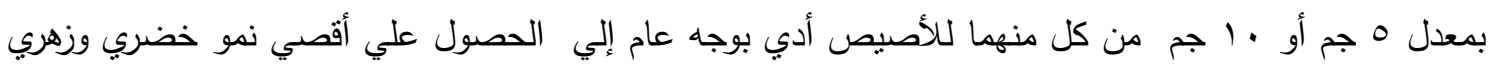
ومحصول للزيت ففي حين أدت زيادة ملوحة مياة الري إلي زيادة نسبة الزيت. 